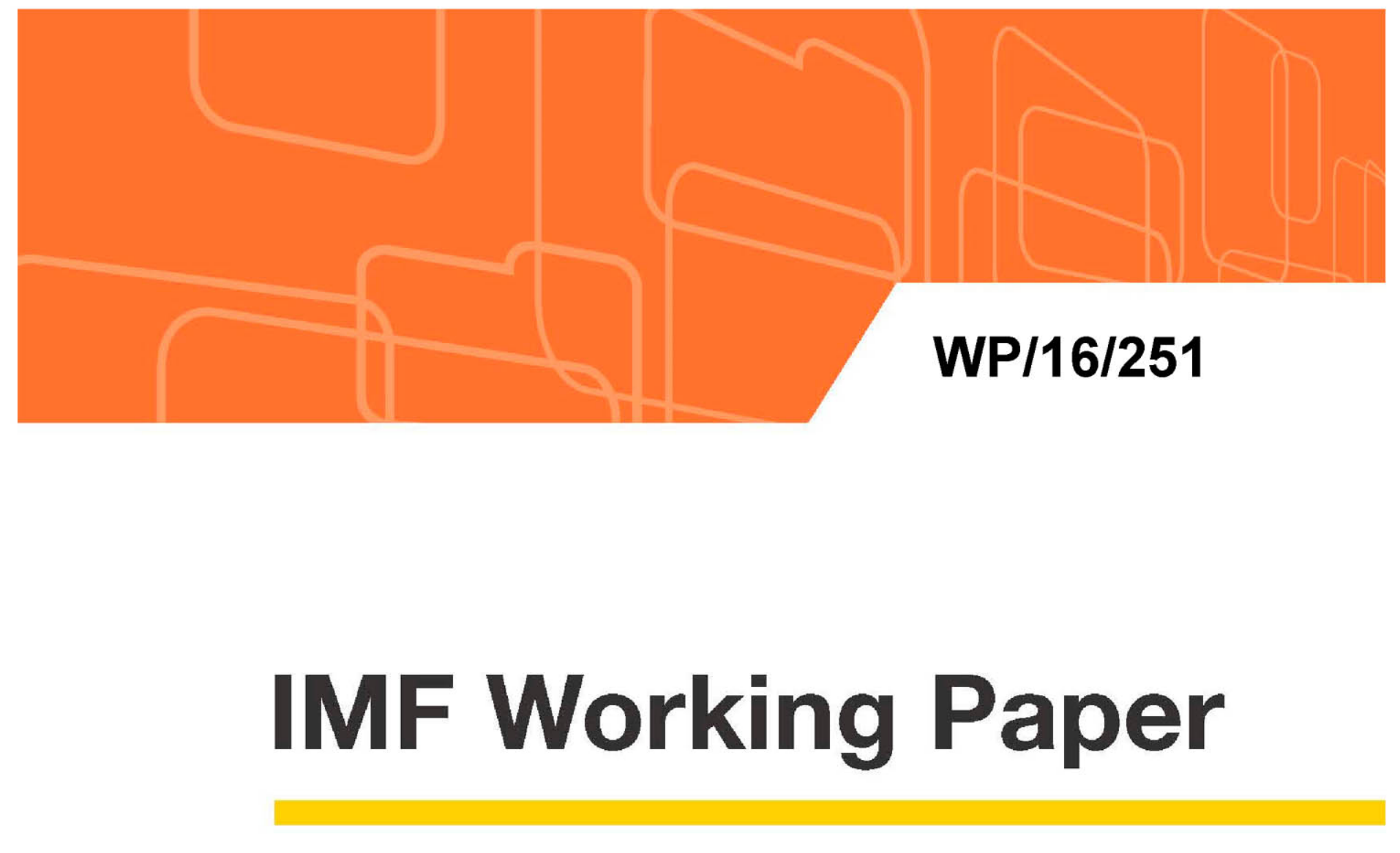

\title{
Financial Information and Macroeconomic Forecasts
}

\author{
by Sophia Chen and Romain Ranciere
}

IMF Working Papers describe research in progress by the author(s) and are published to elicit comments and to encourage debate. The views expressed in IMF Working Papers are those of the author(s) and do not necessarily represent the views of the IMF, its Executive Board, or IMF management. 


\title{
WP/16/251
}

\section{IMF Working Paper}

\section{Financial Information and Macroeconomic Forecasts}

\author{
by Sophia Chen and Romain Ranciere
}

IMF Working Papers describe research in progress by the author(s) and are published to elicit comments and to encourage debate. The views expressed in IMF Working Papers are those of the author(s) and do not necessarily represent the views of the IMF, its Executive Board, or IMF management.

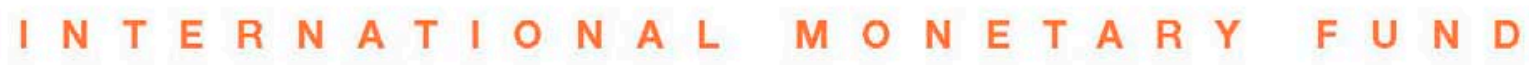




\title{
RightsLink
}

\section{IMF Working Paper}

Research Department

\section{Financial Information and Macroeconomic Forecasts \\ Prepared by Sophia Chen and Romain Ranciere ${ }^{1}$}

Authorized for distribution by Maria Soledad Martinez Peria

December 2016

\section{IMF Working Papers describe research in progress by the author(s) and are published to elicit comments and to encourage debate. The views expressed in IMF Working Papers are those of the author(s) and do not necessarily represent the views of the IMF, its Executive Board, or IMF management.}

\begin{abstract}
We study the forecasting power of financial variables for macroeconomic variables for 62 countries between 1980 and 2013. We find that financial variables such as credit growth, stock prices and house prices have considerable predictive power for macroeconomic variables at one to four quarters horizons. A forecasting model with financial variables outperforms the World Economic Outlook (WEO) forecasts in up to 85 percent of our sample countries at the four quarters horizon. We also find that cross-country panel models produce more accurate out-of-sample forecasts than individual country models.

JEL Classification Numbers: C53, E44, E47

Keywords: Macroeconomic Forecasting, Financial Markets and the Macroeconomy, Credit Growth, Stock Price, House Price

Author's E-Mail Address: YChen2@imf.org, RRanciere@imf.org
\end{abstract}

\footnotetext{
${ }^{1}$ We thank Giovanni Dell'Ariccia and Prakash Loungani for useful comments and suggestions. We thank Yangfan Sun for excellent research assistance. All remaining errors are ours.
} 


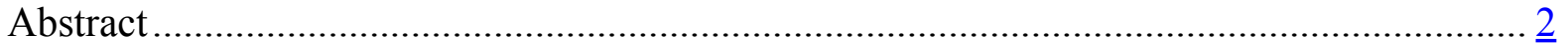

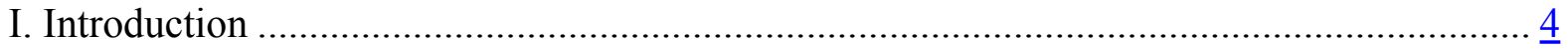

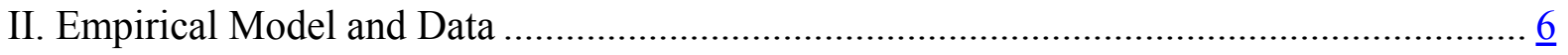

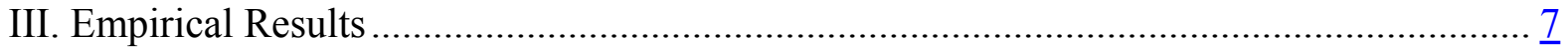

A. Panel Estimation Results..................................................................................

B. Panel versus Country-Specific Forecasts: In-sample and Out-of-Sample Results .......... $\underline{9}$

C. Comparison with WEO Forecasts ......................................................................... 10

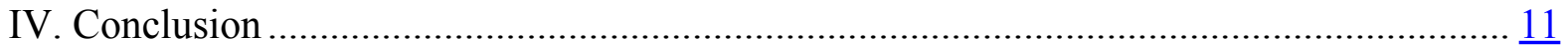

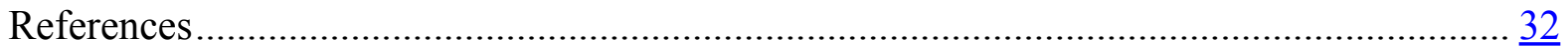

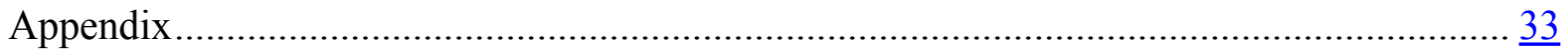

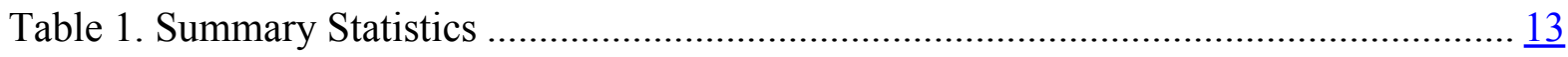

Table 2. Panel Regression Results: All Countries ………………………………………..... $\frac{15}{17}$

Table 3. Panel Regression Results: Advanced Economies............................................... $\frac{17}{19}$

Table 4. Panel Regression Results: Advanced Economies Subsample with Bond Yields ..... $\frac{19}{23}$

Table 5. Panel Regression Results: Emerging Markets ....................................................... $\frac{23}{23}$

Table 6. Panel Regression Results: Low-Income Countries................................................... 25

Table 7. Comparing Panel and Individual Country Model Performance: Advanced

Economies............................................................................................................... 26

Table 8. Comparing Panel and Individual Country Model Performance: Emerging Markets $\underline{28}$

Table 9. Comparing WEO Forecasts with Simple Financial Model ……………………….. $\underline{30}$

Table 10. Comparing WEO Forecasts with Expanded Financial Model................................. 


\section{INTRODUCTION}

The crisis of 2007 to 2009 - originated from the U.S. subprime mortgage market — caused widespread disruptions in the financial market including contraction in credit supplies and declines in asset prices. The crisis was followed by the global economic downturn of the Great Recession that spread to virtually all advanced economies and many emerging markets. These developments have contributed to an intense debate on macro-financial linkages.

In this paper, we study macro-financial linkages in the context of macroeconomic forecasts. Building our analysis on a large literature on macroeconomic forecasts, we examine the forecasting power of financial variables for macroeconomic variables for 62 countries between 1980 and 2013. We show that incorporating financial variables such as credit growth, stock prices, house prices, and bond yields in an otherwise simple model significantly improves the accuracy of macroeconomic forecasts.

The rational of using financial variables to forecast macroeconomic variables is threefold. First, in the presence of financial market imperfections when the Modigliani-Miller theorem does not hold, changes in credit conditions are likely to result in changes in future macroeconomic conditions. In addition, changes in asset prices, by affecting the wealth of firms and households, affect their investment and consumption decisions. Second, financial variables, by their forward-looking nature, incorporate information about the future of the economy that are not yet reflected in current macroeconomic outcomes. Finally, in countries where macroeconomic variables are collected with considerable time lags, contemporaneous financial variables can help nowcasting these variables.

Our methodology is chosen to be deliberately simple to facilitate easy replication. The model can be estimated either country-by-country or in a cross-country panel. The simplicity of the model makes it applicable to countries with very limited financial data. In its simplest specification, the model uses only one financial variable that is available for most countries: private sector credit growth. ${ }^{2}$ For countries with available data, the model can be augmented to include additional financial variables such as stock prices, house prices, corporate and sovereign bond yields, and deposit and borrowing rates.

We find that credit growth is significantly associated with GDP growth. The effect is large in the baseline model with only one financial variable: credit growth. In nowcasting, a one standard deviation increase in credit growth (i.e. a 24 percentage point increase in annualized rate) is associated with a 1.79 percentage point increase in annualized GDP growth, which corresponds to about 1/3 of one standard deviation of the annualized GDP growth in our sample. A one standard deviation increase in credit growth is associated with 1.15 percentage point increase in GDP growth at one quarter ahead horizon, and a 0.46 percentage point increase at four quarters ahead horizon. In the augmented model with other financial variables, the effect of credit growth remains significant in nowcasting and at one quarter horizon.

\footnotetext{
${ }^{2}$ As of end-2015, the IMF's International Financial Statistics (IFS) has data on private sector credit annually for over 180 economies and quarterly for over 120 economies.
} 
Credit growth is also significantly associated with consumption growth, investment growth, and inflation. The effect is strongest for investment growth. A one standard deviation increase in credit growth is associated with a 6.9 percentage point increase in investment growth in nowcasting, a 4.2 percentage point increase at one-quarter horizon, and a 2.0 percentage point increase at four-quarter horizon.

Conditional on credit growth, stock prices and house prices also predict GDP growth, consumption growth, and investment growth in most of the specifications. Conditional on these variables, deposit and lending rates have little predictive power for macro variables with one exception. The lending rate is strongly positively associated with future investment growth. Corporate and sovereign bond yields also have some predictive power for macro variables. But their effects are not robust when other financial variables are included.

Our findings are robust across different country groups (i.e. advanced economies, emerging markets and low-income countries). ${ }^{3}$ In particular, credit growth is significantly associated with GDP growth in all country groups. The coefficients tend to be larger among emerging market and low-income countries than among advanced economies. The only exception is that when sovereign and corporate bond yields are included, credit growth loses statistical significance. Stock prices and house prices also retain predictive power for advanced economies and emerging markets. ${ }^{4}$

Given that similar empirical relationships hold across countries, a natural question to ask is whether cross country information helps to predict individual country's macro outcomes. To answer this question, we compare the performance of our model based on individual country regressions to those based on panel regressions. We find that the out-of-sample forecasts based on panel regressions always outperform those based on individual country regressions even though individual country regressions always have better in-sample fit. Our result suggests that cross country information helps to improve individual country forecast.

To assess the forecasting performance of our models, we compare the out-of-sample forecasting errors of our models with those from a benchmark model in which macroeconomic variables are forecasted based on past macroeconomic outcomes. We also compare the forecasting errors of our model with those implied by publicly available forecasts from the IMF's World Economic Outlook (WEO). The WEO publishes biannually IMF's projections on national accounts and other indicators for member countries. We find that our financial models have more accurate forecasts for GDP growth than WEO predictions. A simple financial model with credit growth has smaller forecasting errors than WEO forecasts for 69 percent of the countries in our sample. An extended financial model

\footnotetext{
${ }^{3}$ We define advanced economies follows the WEO classification. We define low income countries as all countries eligible to obtain concessional financing (Poverty Reduction and Growth Trust, or PRGT) from the IMF (IMF 2016). The rest of the countries are in the emerging market group. One exception is Bolivia, which graduated from PRGT-eligibility on October 16, 2015 but is included in our low-income countries regression.

${ }^{4}$ We do not have data on stock prices or house prices for low income countries.
} 
with credit growth, stock prices, and house prices has smaller forecasting errors than WEO forecasts for 85 percent of the countries.

The paper draws on several strands of the literature. First, it builds on a recent literature showing that credit conditions are driving part of business cycle fluctuations (Bernanke, Gertler, and Gilchrist, 1996; Gilchrist and Zakrajsek, 2012; Philippon, 2009). Second, our results are consistent with prior empirical evidence that financial variables are leading indicators of business cycles, as shown by Leamer (2007) for house price, and by Claessens, Kose, and Torrones (2009) and Estrella and Mishkin (1998) for other financial variables. From a methodological perspective, this paper relates to the discussion of the pros and cons of using pooled international data in forecast models (Garcia-Ferrer, et al., 1987; Hoogstrate, Palm, and Pfann. 2000)

Prior empirical research on macro financial forecasts mostly explores the procyclical nature of financial variables in a small set of advanced economies. In particular, most studies focus on forecasting macroeconomic activities using asset prices, broadly defined to include interest rates, interest spreads, returns, and the value of financial and tangible assets such as bonds, stocks, and housing (for a literature review, see Stock and Watson, 2003). Asset prices data has the advantage of being observed in real time with small measurement errors. However, it is only available for a limited set of countries. Our paper contributes to this literature by broadening our understanding of these relationships with a model and data that is applicable to a large number of countries.

The rest of the paper is organized as follows. Section 2 introduces our forecasting model and data. Section 3 present our results. Section 4 concludes.

\section{EMPIRICAL MOdel ANd DATA}

To assess the predictive ability of financial variables for macroeconomic activity, we estimate the following forecasting model:

$$
\nabla^{h} Y_{c, t+h}=\alpha+\sum_{i=1}^{p} \beta_{i} \nabla Y_{c, t-i}+\gamma X_{c t}+\mu_{c}+\varepsilon_{c, t+h},
$$

where $Y_{c t}$ is a quarterly macroeconomic indicator (to be specified below) for country $c$ in quarter $t$. $\nabla^{h} Y_{c, t+h} \equiv z /(h+1) \ln \left(Y_{t+h} / Y_{t-1}\right)$ measures the annualized growth rate, where $h \geq 0$ is the forecast horizon. $z=400$ is a scaling constant. $X_{c t}$ is a vector of predictors. $\mu_{c}$ is country fixed effect. We include the lagged value $\nabla Y_{c, t-i}$ as predictors because the left-handside variable is likely to be serially correlated. Thus the coefficient $\gamma$ captures the marginal information content of predictors $X_{c t}$ beyond that contained in $\nabla Y_{c, t-i}$. We use Akaike Information Criterion (AIC) to determine the lag length $p$ in each specification. We use Newey-West standard errors to correct for the autocorrelation and heteroskedasticity of the 
moving-average error term $\varepsilon_{c, t+h}$ resulting from overlapping observations. ${ }^{5}$ The timing adopted by this framework allows for "nowcasting" (i.e. $h=0$ ), in which contemporaneous financial variables are used to forecast macroeconomic activities. This is most useful when macroeconomic indicators are observed with lags but contemporaneous financial variables are readily available.

We consider the following key measures of macroeconomic activities on the left-hand side: GDP growth, private consumption growth, private investment growth, and consumer price indexes (CPI) inflation. We use a vector of financial variables as predictors including private sector credit growth, stock prices, and house prices, the bank prime loan rate, and the deposit rate. For a subsample of advanced economies for which data is available, we also estimate an extended model with additional data on sovereign bond yields and corporate bond yields. The main sources for house prices are the OECD and the Bank of International Settlements (BIS). The main source for stock prices and bond yields is Bloomberg. We use two policy controls: government consumption as a proxy for fiscal policy and short term interest rate as a proxy for monetary policy. GDP, consumption, investment, and all financial variables are converted into real terms using country-specific GDP deflator. For all variables that are not seasonally adjusted in the raw data, we perform seasonal adjustment using the X-12-ARIMA method proposed by the U.S. Census Bureau. Table A1 in the Appendix summarizes data sources for each of the variables.

There are considerable variations in the availability of quarterly data over 1980-2013 even in the sample of advanced economies. While some countries such as France, US, or Japan have a quasi-exhaustive data coverage for the baseline model, others such as Sweden, Germany or Netherlands exhibit significant data gaps. Using data for corporate bond yields significantly reduces the sample coverage for advanced economies. Moreover, the number of quarterly observations is larger for advanced than for emerging countries. While there are, on average, 87 quarterly observations per country for advanced economies, there are, on average, only 41 quarterly observations per country for emerging economies. We present summary statistics in Table 1. We present the list of countries included in our regressions in Appendix Table A2.

\section{EMPIRICAL RESULTS}

Because the data coverage is very unbalanced across countries, we estimate the model for the sample of all countries and for four different subsamples of countries: two for advanced economies (AE), one for emerging markets (EM), and one for low-income countries (LIC). For advanced economies, we first present results for all countries using the baseline specification. We then present results for the extended model with sovereign bond yields and corporate bond yields for the subsample of countries for which data are available. Finally, we compare forecasting errors of the panel models with those of the individual country models, and with those implied by IMF's WEO forecasts, on an in-sample and out-of-sample basis.

\footnotetext{
${ }^{5}$ In another specification (not shown), we also include up to 2 lags of financial variables. Our main results are not affected.
} 


\section{A. Panel Estimation Results}

Table 2 presents the panel regressions on the sample of all countries with available data. Panel A and B present the results for GDP growth and consumption growth, while Panel C and $\mathrm{D}$ present the results for investment and inflation. In each panel, columns 1 to 3 presents nowcasting results, columns 4 to 6 forecasting results at one quarter ahead horizon, and columns 7 to 9 forecasting results at four quarters ahead horizon.

We present three specifications: a baseline specification with credit growth and the policy controls (government consumption and policy rate), and two augmented specifications: one that adds stock prices and house prices, and another one that further adds deposit and lending rates. Compared to the baseline specification, using the most comprehensive set of variables leads to a reduction of the number of observations by about one half. In order to be able to compare the relative importance of predictor variables, we report standardized coefficients for all financial variables and policy controls.

Credit growth is significantly associated with GDP growth in most specifications. The effect is large in our baseline specifications. In nowcasting, a one standard deviation increase in credit growth (i.e. a 24 percentage point increase in annualized rate) is associated with a 1.79 percentage point increase in annualized GDP growth, which corresponds to about 1/3 of one standard deviation of the annualized GDP growth in our sample. A one standard deviation increase in credit growth is associated with 1.15 percentage point increase in GDP growth at one quarter ahead horizon, and a 0.46 percentage point increase at four quarters ahead horizon. In the augmented specifications, the effect remains significant for nowcasting and at one quarter ahead horizon with a slightly smaller effect $(0.87$ percentage point and 0.96 percentage points for nowcasting; and 0.65 percentage point and 0.43 percentage point at the one quarter ahead horizon). But credit growth is not statistically significant at four quarters ahead horizon. Credit growth similarly has forecasting power for consumption growth and investment growth. However, the effect of credit growth on investment growth is not significant in the augmented specifications. Credit growth is negatively associated with inflation growth but the effect tends to vanish in augmented specifications and at four quarters ahead horizon.

Stock prices and house prices are positively associated with GDP growth in all specifications. The effects are significant at one percent confidence level and tend to be large. At one quarter ahead horizon, a one standard deviation increase in either the house price index or the stock price index lead to an increase in GDP growth of 0.95 percentage point. The effect at four quarters horizon remains strong: 0.73 percentage point for the stock price index and 0.85 percentage point for house prices index. The effect for nowcasting is slightly smaller for the stock price index ( 0.59 percentage point) but larger for the house prices index (1.01 percentage points). Stock prices and house prices also predict consumption growth. An increase in house prices has a stronger impact on consumption growth than an increase in stock prices. This result is not surprising given than housing wealth represents 50 percent or more of total household wealth (ECB 2004, Iacoviello 2012). Stock and house prices also have a large and significant impact on investment growth in most specification. Neither stock prices nor house prices significantly predict inflation. 
Conditional on other financial variables and policy controls, the deposit and lending rates do not significantly predict GDP growth. An increase in the deposit rate does predict lower consumption growth and higher investment growth in the future.

Table 3 presents similar results for advanced economies which broadly confirms the results obtained for the full sample. The same is true for the sample of advanced economies with information on sovereign bond yields (Table 4), but the impact of credit growth is weaker in that sample. A one standard deviation increase in the corporate bond yield leads to a percentage reduction in GDP growth of 0.7 and 0.75 percentage points at one and fourth quarter horizon respectively in the baseline specification. The negative effect is smaller $(0.48$ percentage point) in the most comprehensive specification and at the four quarters ahead horizon. An increase in the corporate bond yield has an even stronger negative effect on investment growth but the results are not robust beyond the baseline specification. The results on corporate bond yields are in line with the findings of Gilchrist and Zakrajsek (2012) for the U.S. economy.

Table 5 presents the results for emerging markets. The effect of credit growth on GDP growth is much stronger than what it is for advanced economies but its forecasting ability is only significant at the one quarter ahead horizon. Another notable difference is that house price growth is negatively correlated with investment growth, and that an increase in the lending rate has a strong negative impact on investment. The first fact is consistent with a house price boom crowding out investment, and the second with the presence of severe borrowing constraints tying up investment to lending conditions in emerging markets.

Table 6 present some more limited results for low-income countries, which also point out towards a large impact of credit growth in forecasting GDP and consumption growth at one quarter and four quarters ahead horizons. We note that these results may be unrepresentative of these group of countries because, due to limited data availability, this sample consists of only 3 countries.

Comparing the in-sample goodness of fit across specifications suggests that the best specification includes credit growth, house prices, stock prices, policy controls and the optimal number of lags of the dependent variable. The adjusted R-square at four quarters ahead horizon for all countries is in the range of 0.25 to 0.3 for investment and GDP growth, and in the range of 0.5 to 0.6 for consumption and inflation.

The regression results indicate a comparable goodness of fit for GDP growth in advanced and in emerging economies, but a much better fit for consumption growth in the advanced economies group than in the emerging markets group (0.62 vs 0.18$)$. The goodness of fit is of similar order of magnitude for investment growth and inflation across both country groups.

\section{B. Panel versus Country-Specific Forecasts: In-sample and Out-of-Sample Results}

In this section, we assess the forecast performance of a panel model estimated with pooled international data and we compare it with the performance of an individual country model estimated with country-specific data. Of particular interest is the extent to which the use of pooled international data can improve forecasting performance. 
We compute the root mean squared errors (RMSE) for each model and subsample. For each subsample of countries (AE, EM, LIC), we report two sets of results: full sample fit and outof-sample forecast on quarterly GDP growth. For full sample fit, we use data for the period 1980-2013. For out-of-sample forecast, we use data for the period 1980-1999 to fit our models. We then use these fitted models to compute four-quarter ahead forecasts for the period 2000-2007. We limit the forecast years prior to 2007 to exclude the period of global financial crisis and subsequent Great Recession. We do this in order to focus our attention on normal times rather than tail events. In periods of financial crisis, the relationship between financial and real variables may be very different. We leave this for future research. To minimize the influence of extreme events, we also drop from the sample observations where the annualized GDP growth rate is great than 30 percent or less than -30 percent.

We assess the performances of three models. The first model is an AR model with the optimal number of lags chosen by AIC for up to 7 lags. The second model is a financial model that augments an AR model with credit growth and two policy controls (policy rate and government consumption). The third model is a financial model that augments an AR model with credit growth, house price growth, stock price growth, and two policy controls.

Table 7 compares panel and individual RMSE in the sample of advanced economies. Panel A present the in-sample results and show that the forecast based on individual country regressions outperform forecasts based on panel regression for all but one country. This finding is reversed when one considers out-of-sample forecasts. In that case panel forecasts display a lower RMSE for all but four advanced countries in the model with credit growth as the only financial variable. In some countries, such as Belgium and Japan, the RMSE is reduced by a factor of 3 .

Table 8 presents results for the group of emerging markets and it yields similar results. While the in-sample forecasts based on individual regressions always outperform those based on panel regressions, the opposite is true for out-of-sample forecasts. All 9 emerging economies, for which data allow for an out-of-sample forecast to be performed, display a smaller RMSE for panel than individual forecasts. The reduction in RMSE associated with using panel regressions can be very substantial with a RMSE divided by about 2 for Turkey and Brazil, by about 4 for Colombia and Peru.

The comparison of panel and individual forecasts is an important result of this paper. While leaving regression coefficient to be country-specific improves in-sample fit, imposing common coefficients in a panel regression gives stronger out-of-sample forecasting power. In other words, cross country information obtained from panel regression helps to improve individual country forecast.

\section{Comparison with WEO Forecasts}

In this section, we compare the forecast performance derived from our financial models with publicly available forecasts included in the World Economic Outlook (WEO) of the IMF. We are interested in examining whether and when our models result in more accurate forecasts than WEO Forecasts. 
The WEO publishes IMF's projections on national accounts and other indicators for member countries. The publication is released in April and September/October each year. For about 50 of the largest countries that account for about 90 percent of world output, the forecasts are updated for each WEO exercise. The WEO at times revises previous forecasts. But we only focus our attention on forecasting errors of the initial forecast, which we obtain by compiling WEO publications of various vintages.

In order to assess the performance of our models in real time, we compute out-of-sample four-quarter ahead forecasts on quarterly GDP growth for each country from 2004 Q1 to 2013 Q1 (i.e. 19 quarters). The forecasts are based on a fitted model estimated with pooled international data in a rolling window of 20 years prior to each forecasting period. The rolling window allows the forecast to be made using the most updated information. We compute the forecasting errors of each model for each country. ${ }^{6}$ We then compare these to the forecasting errors of WEO forecasts based on four-quarter ahead forecast made each year on April (i.e. Q1) and September/October (i.e. Q3) for each country from 2004 Q1 to 2013 Q1.

We access the performances of two financial models. A simple financial model is a model that augments an AR model with credit growth and two policy controls (policy rate and government consumption). An expanded financial model is a model that augments an AR model with credit growth, stock prices, house prices, and two policy controls.

Table 9 and 10 compare the RMSE of the two models to the RMSE implied by WEO forecasts. Forecasts based on the simple financial model outperform WEO forecasts in 69 percent of the countries in our sample. When the financial model is augmented to include stock and house prices, its RMSE is further reduced. The out-of-sample forecasts of the expanded financial model are more accurate than the WEO forecasts in 85 percent of countries in our sample. Our results suggest that incorporating financial information and pooled international data can potentially improve the accuracy of macroeconomic forecasts in the medium horizon for a large number of countries.

\section{Conclusion}

Obtained with a simple and easily replicable empirical framework, the results of this paper provide ample support for the hypothesis that financial variables contain information that can be used to forecast macroeconomic variables at up to four quarters horizon. Such information comes from both quantity variables such as credit growth and price variables such as stock and house prices. The forecasting power of financial variables is present in advanced and emerging, and low-income economies.

\footnotetext{
${ }^{6}$ Our models do not make predictions if one or more predictors are missing. As a result, the RMSE for some countries are based on less than 19 forecasts. The RMSE of WEO forecasts for some countries are based on less than 19 forecasts due to data availability,
} 
The paper sheds light on the relative merits of country-specific and panel models for macroeconomic forecasting. While not surprisingly, country-specific models provide a better in-sample fit, panel models provide more accurate out-of-sample forecasts. Exploring more systematically why this is the case is an interesting avenue for future research.

Running a horse-race between our models' forecasts and the WEO forecasts reveals that incorporating financial information and pooled international data can improve the accuracy of WEO forecasts for up to 85 percent of the countries in our sample. Comparing our forecasts to other benchmarks would be a natural extension of this paper. 
Table 1. Summary Statistics

\begin{tabular}{lccccccc}
\hline \hline & Country & $\begin{array}{c}\text { No. of } \\
\text { Obs }\end{array}$ & Mean & $\begin{array}{c}\text { Std. } \\
\text { Dev }\end{array}$ & Min & Median & Max \\
\hline Macro Variables & & & & & & & \\
GDP growth (\%) & All & 6276 & 3.076 & 8.247 & -18.330 & 2.968 & 22.633 \\
Consumption growth (\%) & All & 6359 & 3.180 & 10.615 & -29.891 & 3.117 & 33.672 \\
Investment growth (\%) & All & 6337 & 2.699 & 25.652 & -74.258 & 3.139 & 73.203 \\
Inflation (\%) & All & 18900 & 10.233 & 17.272 & -10.293 & 5.226 & 88.776 \\
\hline Financial Variables & & & & & & & \\
Credit growth (\%) & All & 17943 & 6.691 & 24.343 & -67.367 & 6.470 & 73.953 \\
Stock price growth (\%) & All & 6290 & 10.802 & 54.356 & -130.262 & 11.976 & 155.151 \\
House price growth (\%) & All & 4946 & 2.632 & 12.292 & -29.403 & 2.133 & 38.173 \\
Deposit rate (\%) & All & 17935 & 9.736 & 10.529 & 0.809 & 6.713 & 59.828 \\
Lending rate (\%) & All & 16714 & 16.693 & 12.254 & 4.250 & 13.400 & 67.770 \\
Sovereign Bond yield (\%) & All & 1834 & -5.928 & 39.968 & -100.151 & -8.559 & 94.837 \\
Corporate Bond yield (\%) & All & 714 & -5.606 & 42.703 & -111.946 & -3.891 & 83.888 \\
\hline Policy variables & & & & & & & 7.496 \\
Government consumption growth (\%) & All & 6752 & 12.068 & 24.500 & -41.569 & 107.523 \\
Policy rate (\%) & All & 14940 & 10.686 & 8.961 & 0.500 & 8.500 & 45.000 \\
\hline
\end{tabular}


Table 2. Summary Statistics (cont')

\begin{tabular}{|c|c|c|c|c|c|c|c|}
\hline & Country & $\begin{array}{c}\text { No. of } \\
\text { Obs }\end{array}$ & Mean & $\begin{array}{l}\text { Std. } \\
\text { Dev }\end{array}$ & Min & Median & Max \\
\hline \multicolumn{8}{|l|}{ Macro Variables } \\
\hline \multirow[t]{3}{*}{ GDP growth (\%) } & $\mathrm{AE}$ & 3478 & 2.219 & 6.749 & -18.330 & 2.275 & 22.633 \\
\hline & EM & 2545 & 3.954 & 9.604 & -18.330 & 4.623 & 22.633 \\
\hline & LIC & 253 & 6.039 & 10.347 & -18.330 & 5.712 & 22.633 \\
\hline \multirow[t]{3}{*}{ Consumption growth (\%) } & $\mathrm{AE}$ & 3448 & 2.612 & 6.929 & -29.891 & 2.481 & 33.672 \\
\hline & EM & 2667 & 3.690 & 13.365 & -29.891 & 4.546 & 33.672 \\
\hline & LIC & 244 & 5.621 & 17.140 & -29.891 & 5.792 & 33.672 \\
\hline \multirow[t]{3}{*}{ Investment growth (\%) } & $\mathrm{AE}$ & 3442 & 1.587 & 19.951 & -74.258 & 1.884 & 73.203 \\
\hline & EM & 2624 & 3.707 & 30.266 & -74.258 & 5.658 & 73.203 \\
\hline & LIC & 271 & 7.082 & 37.748 & -74.258 & 10.784 & 73.203 \\
\hline \multirow[t]{3}{*}{ Inflation $(\%)$} & $\mathrm{AE}$ & 4150 & 4.951 & 9.267 & -10.293 & 3.005 & 88.776 \\
\hline & EM & 8045 & 12.342 & 19.550 & -10.293 & 6.217 & 88.776 \\
\hline & LIC & 6705 & 10.971 & 17.494 & -10.293 & 6.676 & 88.776 \\
\hline \multicolumn{8}{|l|}{ Financial Variables } \\
\hline \multirow[t]{3}{*}{ Credit growth (\%) } & $\mathrm{AE}$ & 3887 & 5.839 & 14.044 & -67.367 & 5.145 & 73.953 \\
\hline & EM & 7635 & 6.995 & 23.199 & -67.367 & 7.244 & 73.953 \\
\hline & LIC & 6421 & 6.847 & 29.936 & -67.367 & 6.998 & 73.953 \\
\hline \multirow[t]{2}{*}{ Stock price growth (\%) } & $\mathrm{AE}$ & 3404 & 7.647 & 45.919 & -130.262 & 11.735 & 155.151 \\
\hline & EM & 2623 & 14.167 & 62.562 & -130.262 & 13.698 & 155.151 \\
\hline \multirow[t]{2}{*}{ House price growth (\%) } & $\mathrm{AE}$ & 3416 & 2.359 & 10.481 & -29.403 & 2.009 & 38.173 \\
\hline & EM & 1530 & 3.241 & 15.581 & -29.403 & 2.412 & 38.173 \\
\hline \multirow[t]{2}{*}{ Deposit rate $(\%)$} & $\mathrm{AE}$ & 3323 & 6.486 & 6.305 & 0.809 & 4.817 & 59.828 \\
\hline & EM & 7641 & 11.670 & 13.015 & 0.809 & 7.420 & 59.828 \\
\hline \multirow[t]{2}{*}{ Lending rate $(\%)$} & $\mathrm{AE}$ & 3455 & 10.716 & 8.535 & 4.250 & 8.500 & 67.770 \\
\hline & EM & 7208 & 17.595 & 13.759 & 4.250 & 13.095 & 67.770 \\
\hline Sovereign Bond yield (\%) & $\mathrm{AE}$ & 1782 & -5.997 & 40.239 & -100.151 & -8.599 & 94.837 \\
\hline Corporate Bond yield (\%) & $\mathrm{AE}$ & 714 & -5.606 & 42.703 & -111.946 & -3.891 & 83.888 \\
\hline \multicolumn{8}{|l|}{ Policy Variables } \\
\hline & $\mathrm{AE}$ & 3616 & 7.084 & 13.904 & -41.569 & 5.739 & 107.523 \\
\hline \multirow[t]{2}{*}{ Government consumption growth (\%) } & EM & 2888 & 18.135 & 31.473 & -41.569 & 12.786 & 107.523 \\
\hline & LIC & 248 & 14.077 & 34.651 & -41.569 & 12.926 & 107.523 \\
\hline \multirow[t]{3}{*}{ Policy rate $(\%)$} & $\mathrm{AE}$ & 3623 & 6.465 & 5.756 & 0.500 & 5.000 & 45.000 \\
\hline & EM & 6249 & 11.521 & 9.695 & 0.500 & 8.500 & 45.000 \\
\hline & LIC & 5068 & 12.674 & 8.923 & 0.500 & 10.250 & 45.000 \\
\hline
\end{tabular}

Notes: AE refers to advanced economies, EM refers to emerging markets, and LIC refers to low-income countries. All variables are winsorized at 2 percent. 
Table 3. Panel Regression Results: All Countries

\begin{tabular}{|c|c|c|c|c|c|c|c|c|c|}
\hline \multirow[b]{2}{*}{ Credit growth } & \multicolumn{3}{|c|}{ Nowcasting } & \multicolumn{3}{|c|}{1 quarter ahead forecast } & \multicolumn{3}{|c|}{4 quarters ahead forecast } \\
\hline & $\begin{array}{c}1.787 * * * \\
{[0.529]}\end{array}$ & $\begin{array}{l}0.873 * \\
{[0.461]}\end{array}$ & $\begin{array}{l}0.959 * * \\
{[0.469]}\end{array}$ & $\begin{array}{c}1.151 * * * \\
{[0.312]}\end{array}$ & $\begin{array}{c}0.653 * * * \\
{[0.230]}\end{array}$ & $\begin{array}{l}0.432 * * \\
{[0.187]}\end{array}$ & $\begin{array}{c}0.468 * * * \\
{[0.175]}\end{array}$ & $\begin{array}{c}0.190 \\
{[0.138]}\end{array}$ & $\begin{array}{c}0.016 \\
{[0.116]}\end{array}$ \\
\hline Stock price & & $\begin{array}{c}0.617 * * * \\
{[0.200]}\end{array}$ & $\begin{array}{c}0.591 * * * \\
{[0.187]}\end{array}$ & & $\begin{array}{c}1.137 * * * \\
{[0.109]}\end{array}$ & $\begin{array}{c}0.949 * * * \\
{[0.155]}\end{array}$ & & $\begin{array}{c}0.861 * * * \\
{[0.079]}\end{array}$ & $\begin{array}{c}0.733 * * * \\
{[0.105]}\end{array}$ \\
\hline House price & & $\begin{array}{c}1.263 * * * \\
{[0.234]}\end{array}$ & $\begin{array}{c}1.013 * * * \\
{[0.268]}\end{array}$ & & $\begin{array}{c}1.194 * * * \\
{[0.198]}\end{array}$ & $\begin{array}{c}0.946 * * * \\
{[0.237]}\end{array}$ & & $\begin{array}{c}1.008 * * * \\
{[0.162]}\end{array}$ & $\begin{array}{c}0.849 * * * \\
{[0.198]}\end{array}$ \\
\hline Deposit rate & & & $\begin{array}{l}1.503 \\
{[3.218]}\end{array}$ & & & $\begin{array}{c}0.623 \\
{[3.047]}\end{array}$ & & & $\begin{array}{l}1.087 \\
{[2.584]}\end{array}$ \\
\hline Lending rate & & & $\begin{array}{c}8.077 \\
{[5.692]}\end{array}$ & & & $\begin{array}{c}8.054 \\
{[5.054]}\end{array}$ & & & $\begin{array}{c}6.132 \\
{[4.605]}\end{array}$ \\
\hline $\begin{array}{l}\text { Government consumption } \\
\text { growth }\end{array}$ & $\begin{array}{c}0.734 * * * \\
{[0.281]}\end{array}$ & $\begin{array}{c}1.232 * * * \\
{[0.389]}\end{array}$ & $\begin{array}{l}0.984 * * \\
{[0.470]}\end{array}$ & $\begin{array}{l}0.512 * * \\
{[0.205]}\end{array}$ & $\begin{array}{c}0.693 * * * \\
{[0.187]}\end{array}$ & $\begin{array}{c}0.486 * * * \\
{[0.174]}\end{array}$ & $\begin{array}{c}0.244 * * * \\
{[0.091]}\end{array}$ & $\begin{array}{c}0.299 * * * \\
{[0.113]}\end{array}$ & $\begin{array}{c}0.146 \\
{[0.092]}\end{array}$ \\
\hline Policy rate & $\begin{array}{c}-0.431 * * \\
{[0.217]} \\
\end{array}$ & $\begin{array}{c}-0.343 \\
{[0.212]} \\
\end{array}$ & $\begin{array}{c}-2.425^{* * *} \\
{[0.543]} \\
\end{array}$ & $\begin{array}{c}-0.483 * * \\
{[0.242]} \\
\end{array}$ & $\begin{array}{l}-0.255 \\
{[0.190]} \\
\end{array}$ & $\begin{array}{c}-2.159 * * * \\
{[0.481]} \\
\end{array}$ & $\begin{array}{l}-0.324 \\
{[0.238]} \\
\end{array}$ & $\begin{array}{l}-0.060 \\
{[0.198]} \\
\end{array}$ & $\begin{array}{c}-1.804 * * * \\
{[0.493]} \\
\end{array}$ \\
\hline $\begin{array}{l}\text { Country fixed effects } \\
\text { Observations } \\
\text { Adjusted } \mathrm{R}^{2} \\
\end{array}$ & $\begin{array}{c}\text { Yes } \\
3,487 \\
0.107 \\
\end{array}$ & $\begin{array}{c}\text { Yes } \\
2,261 \\
0.112 \\
\end{array}$ & $\begin{array}{c}\text { Yes } \\
1,547 \\
0.086 \\
\end{array}$ & $\begin{array}{c}\text { Yes } \\
3,478 \\
0.151 \\
\end{array}$ & $\begin{array}{c}\text { Yes } \\
2,254 \\
0.224 \\
\end{array}$ & $\begin{array}{c}\text { Yes } \\
1,544 \\
0.165 \\
\end{array}$ & $\begin{array}{c}\text { Yes } \\
3,381 \\
0.248 \\
\end{array}$ & $\begin{array}{c}\text { Yes } \\
2,205 \\
0.290 \\
\end{array}$ & $\begin{array}{c}\text { Yes } \\
1,520 \\
0.265 \\
\end{array}$ \\
\hline \multicolumn{10}{|c|}{ Panel B: Consumption Growth } \\
\hline & \multicolumn{3}{|c|}{ Nowcasting } & \multicolumn{3}{|c|}{1 quarter ahead forecast } & \multicolumn{3}{|c|}{4 quarters ahead forecast } \\
\hline Credit growth & $\begin{array}{c}2.977 * * * \\
{[0.778]}\end{array}$ & $\begin{array}{l}1.118^{* *} \\
{[0.466]}\end{array}$ & $\begin{array}{l}0.580 * \\
{[0.333]}\end{array}$ & $\begin{array}{c}1.480 * * * \\
{[0.399]}\end{array}$ & $\begin{array}{l}0.639 * * \\
{[0.309]}\end{array}$ & $\begin{array}{c}0.321 \\
{[0.253]}\end{array}$ & $\begin{array}{c}0.707 * * * \\
{[0.247]}\end{array}$ & $\begin{array}{l}0.359 * * \\
{[0.157]}\end{array}$ & $\begin{array}{c}0.183 \\
{[0.127]}\end{array}$ \\
\hline Stock price & & $\begin{array}{l}0.560^{* *} \\
{[0.220]}\end{array}$ & $\begin{array}{c}0.121 \\
{[0.162]}\end{array}$ & & $\begin{array}{c}0.679 * * * \\
{[0.140]}\end{array}$ & $\begin{array}{c}0.351 * * * \\
{[0.118]}\end{array}$ & & $\begin{array}{c}0.587 * * * \\
{[0.079]}\end{array}$ & $\begin{array}{c}0.395 * * * \\
{[0.090]}\end{array}$ \\
\hline House price & & $\begin{array}{c}1.739 * * * \\
{[0.220]}\end{array}$ & $\begin{array}{c}1.498 * * * \\
{[0.252]}\end{array}$ & & $\begin{array}{c}1.463 * * * \\
{[0.201]}\end{array}$ & $\begin{array}{c}1.300 * * * \\
{[0.207]}\end{array}$ & & $\begin{array}{c}0.991 * * * \\
{[0.128]}\end{array}$ & $\begin{array}{c}0.795 * * * \\
{[0.138]}\end{array}$ \\
\hline Deposit rate & & & $\begin{array}{c}2.398 \\
{[2.587]}\end{array}$ & & & $\begin{array}{c}1.287 \\
{[2.321]}\end{array}$ & & & $\begin{array}{l}-0.294 \\
{[1.933]}\end{array}$ \\
\hline Lending rate & & & $\begin{array}{c}1.199 \\
{[4.924]}\end{array}$ & & & $\begin{array}{c}3.555 \\
{[4.631]}\end{array}$ & & & $\begin{array}{c}5.764 \\
{[3.795]}\end{array}$ \\
\hline $\begin{array}{l}\text { Government consumption } \\
\text { growth }\end{array}$ & $\begin{array}{c}0.153 \\
{[0.626]}\end{array}$ & $\begin{array}{c}0.249 \\
{[0.324]}\end{array}$ & $\begin{array}{c}0.254 \\
{[0.405]}\end{array}$ & $\begin{array}{l}0.749^{*} \\
{[0.389]}\end{array}$ & $\begin{array}{l}0.363^{*} \\
{[0.208]}\end{array}$ & $\begin{array}{c}0.183 \\
{[0.202]}\end{array}$ & $\begin{array}{l}0.552 * * \\
{[0.268]}\end{array}$ & $\begin{array}{c}0.132 \\
{[0.114]}\end{array}$ & $\begin{array}{l}-0.021 \\
{[0.094]}\end{array}$ \\
\hline Policy rate & $\begin{array}{c}-1.478 * * \\
{[0.632]}\end{array}$ & $\begin{array}{c}-0.008 \\
{[0.213]}\end{array}$ & $\begin{array}{c}-1.282 * * \\
{[0.648]}\end{array}$ & $\begin{array}{c}-1.507 * * \\
{[0.610]}\end{array}$ & $\begin{array}{l}-0.103 \\
{[0.191]}\end{array}$ & $\begin{array}{c}-1.343^{* *} \\
{[0.611]}\end{array}$ & $\begin{array}{c}-1.141 * * \\
{[0.462]}\end{array}$ & $\begin{array}{c}0.006 \\
{[0.173]}\end{array}$ & $\begin{array}{c}-1.208^{* * * *} \\
{[0.462]}\end{array}$ \\
\hline Country fixed effects & Yes & Yes & Yes & Yes & Yes & Yes & Yes & Yes & Yes \\
\hline Observations & 4,274 & 2,647 & 1,906 & 4,237 & 2,636 & 1,899 & 4,125 & 2,591 & 1,868 \\
\hline Adjusted R ${ }^{2}$ & 0.143 & 0.222 & 0.214 & 0.191 & 0.352 & 0.357 & 0.293 & 0.508 & 0.552 \\
\hline
\end{tabular}


Table 2. Panel Regression Results: All Countries (cont')

\begin{tabular}{|c|c|c|c|c|c|c|c|c|c|}
\hline \multirow{3}{*}{ Credit growth } & \multicolumn{3}{|c|}{ Nowcasting } & \multicolumn{3}{|c|}{1 quarter ahead forecast } & \multicolumn{3}{|c|}{4 quarters ahead forecast } \\
\hline & $6.925 * * *$ & $3.134 * *$ & 1.834 & $4.161 * * *$ & 2.244 & 0.631 & $2.046 * * *$ & 0.791 & 0.155 \\
\hline & {$[1.706]$} & [1.526] & [1.204] & [1.344] & [1.493] & {$[0.714]$} & {$[0.656]$} & {$[0.495]$} & {$[0.359]$} \\
\hline \multirow[t]{2}{*}{ Stock price } & & $1.375 * * *$ & 0.333 & & $2.698 * * *$ & $1.342 * * *$ & & 0.364 & $1.666 * * *$ \\
\hline & & {$[0.518]$} & {$[0.482]$} & & {$[0.748]$} & {$[0.352]$} & & {$[0.244]$} & {$[0.282]$} \\
\hline \multirow[t]{2}{*}{ House price } & & $4.576 * * *$ & $4.047 * * *$ & & $4.222 * * *$ & $3.663 * * *$ & & $-2.345 * * *$ & $3.031 * * *$ \\
\hline & & {$[0.802]$} & {$[0.744]$} & & {$[0.592]$} & {$[0.683]$} & & {$[0.570]$} & {$[0.533]$} \\
\hline \multirow[t]{2}{*}{ Deposit rate } & & & 2.824 & & & 2.525 & & & -1.887 \\
\hline & & & [9.197] & & & {$[8.046]$} & & & {$[6.895]$} \\
\hline \multirow[t]{2}{*}{ Lending rate } & & & $27.216^{*}$ & & & $28.851^{* *}$ & & & $29.254 * * *$ \\
\hline & & & {$[14.620]$} & & & {$[12.407]$} & & & {$[9.405]$} \\
\hline \multirow{4}{*}{$\begin{array}{l}\text { Government consumption } \\
\text { growth } \\
\text { Policy rate }\end{array}$} & 0.761 & 0.665 & 0.449 & $0.857 *$ & $0.742 * *$ & 0.493 & $0.660 * *$ & 0.364 & 0.230 \\
\hline & {$[0.884]$} & {$[0.575]$} & {$[0.631]$} & {$[0.486]$} & {$[0.360]$} & {$[0.402]$} & {$[0.293]$} & {$[0.244]$} & {$[0.219]$} \\
\hline & $-3.291 * * *$ & $-2.407 * * *$ & $-8.760 * * *$ & $-2.932 * * *$ & $-2.542 * * *$ & $-8.852 * * *$ & $-2.656^{* * *}$ & $-2.345 * * *$ & $-7.841 * * *$ \\
\hline & [0.939] & {$[0.725]$} & [2.202] & {$[0.792]$} & [0.653] & [1.907] & [0.684] & {$[0.570]$} & [1.511] \\
\hline Country fixed effects & Yes & Yes & Yes & Yes & Yes & Yes & Yes & Yes & Yes \\
\hline Observations & 4,186 & 2,573 & 1,832 & 4,153 & 2,565 & 1,828 & 4,050 & 2,526 & 1,803 \\
\hline Adjusted $\mathrm{R}^{2}$ & 0.083 & 0.089 & 0.083 & 0.083 & 0.184 & 0.164 & 0.115 & 0.257 & 0.274 \\
\hline \multicolumn{10}{|l|}{ Panel D: Inflation } \\
\hline & \multicolumn{3}{|c|}{ Nowcasting } & \multicolumn{3}{|c|}{1 quarter ahead forecast } & \multicolumn{3}{|c|}{4 quarters ahead forecast } \\
\hline \multirow[t]{2}{*}{ Credit growth } & $-3.669 * *$ & $-0.650 * * *$ & $-0.586 * * *$ & $-1.790 *$ & $-0.229 * *$ & -0.062 & -0.717 & 0.064 & 0.209 \\
\hline & [1.833] & [0.184] & {$[0.203]$} & {$[0.940]$} & {$[0.107]$} & {$[0.114]$} & {$[0.461]$} & {$[0.101]$} & {$[0.146]$} \\
\hline \multirow[t]{2}{*}{ Stock price } & & 0.097 & 0.095 & & 0.065 & 0.083 & & 0.025 & 0.036 \\
\hline & & {$[0.083]$} & {$[0.105]$} & & {$[0.068]$} & {$[0.083]$} & & {$[0.075]$} & {$[0.073]$} \\
\hline \multirow[t]{2}{*}{ House price } & & $-0.496^{* *}$ & $-0.585^{* *}$ & & -0.300 & -0.392 & & 0.055 & 0.050 \\
\hline & & {$[0.209]$} & {$[0.283]$} & & {$[0.217]$} & {$[0.290]$} & & {$[0.143]$} & {$[0.175]$} \\
\hline \multirow[t]{2}{*}{ Deposit rate } & & & -1.312 & & & -1.272 & & & -0.750 \\
\hline & & & [1.899] & & & [2.049] & & & [1.903] \\
\hline \multirow[t]{2}{*}{ Lending rate } & & & -6.009 & & & -5.013 & & & -2.368 \\
\hline & & & {$[3.837]$} & & & [3.859] & & & [3.004] \\
\hline \multirow{4}{*}{$\begin{array}{l}\text { Government consumption } \\
\text { growth } \\
\text { Policy rate }\end{array}$} & 1.672 & 0.150 & 0.166 & 1.019 & 0.174 & 0.227 & 0.302 & $0.143 * *$ & $0.167^{*}$ \\
\hline & {$[1.258]$} & {$[0.123]$} & {$[0.152]$} & {$[0.780]$} & {$[0.110]$} & {$[0.145]$} & [0.293] & {$[0.067]$} & {$[0.085]$} \\
\hline & $3.543 * * *$ & $1.889 * * *$ & $3.037 * * *$ & $3.941 * * *$ & $1.791 * * *$ & $2.897 * * *$ & $4.430 * * *$ & $1.634 * * *$ & $2.410 * * *$ \\
\hline & [1.187] & {$[0.357]$} & [0.933] & [1.372] & {$[0.424]$} & [1.052] & [1.488] & {$[0.462]$} & {$[0.900]$} \\
\hline Country fixed effects & Yes & Yes & Yes & Yes & Yes & Yes & Yes & Yes & Yes \\
\hline Observations & 4,544 & 2,746 & 1,988 & 4,510 & 2,738 & 1,986 & 4,402 & 2,698 & 1,959 \\
\hline Adjusted $\mathrm{R}^{2}$ & 0.506 & 0.540 & 0.551 & 0.536 & 0.551 & 0.559 & 0.548 & 0.587 & 0.586 \\
\hline
\end{tabular}


Table 4. Panel Regression Results: Advanced Economies

Panel A: GDP Growth

\begin{tabular}{|c|c|c|c|c|c|c|c|c|c|}
\hline \multirow[b]{2}{*}{ Credit growth } & \multicolumn{3}{|c|}{ Nowcasting } & \multicolumn{3}{|c|}{1 quarter ahead forecast } & \multicolumn{3}{|c|}{4 quarters ahead forecast } \\
\hline & $\begin{array}{l}1.000^{* *} \\
{[0.404]}\end{array}$ & $\begin{array}{c}0.517 \\
{[0.363]}\end{array}$ & $\begin{array}{c}0.543 \\
{[0.336]}\end{array}$ & $\begin{array}{c}0.728 * * * \\
{[0.279]}\end{array}$ & $\begin{array}{l}0.477^{* *} \\
{[0.194]}\end{array}$ & $\begin{array}{l}0.236^{*} \\
{[0.124]}\end{array}$ & $\begin{array}{l}0.369 * * \\
{[0.178]}\end{array}$ & $\begin{array}{c}0.156 \\
{[0.135]}\end{array}$ & $\begin{array}{c}-0.025 \\
{[0.106]}\end{array}$ \\
\hline Stock price & & $\begin{array}{c}0.470 * * \\
{[0.185]}\end{array}$ & $\begin{array}{l}0.390^{* *} \\
{[0.155]}\end{array}$ & & $\begin{array}{c}0.950 * * * \\
{[0.099]}\end{array}$ & $\begin{array}{c}0.645 * * * \\
{[0.124]}\end{array}$ & & $\begin{array}{c}0.721 * * * \\
{[0.071]}\end{array}$ & $\begin{array}{c}0.556^{* * *} \\
{[0.093]}\end{array}$ \\
\hline House price & & $\begin{array}{c}1.336^{* * *} \\
{[0.258]}\end{array}$ & $\begin{array}{c}1.180^{* * *} \\
{[0.314]}\end{array}$ & & $\begin{array}{c}1.380 * * * \\
{[0.217]}\end{array}$ & $\begin{array}{c}1.206 * * * \\
{[0.260]}\end{array}$ & & $\begin{array}{c}1.160 * * * \\
{[0.177]}\end{array}$ & $\begin{array}{c}1.063 * * * \\
{[0.204]}\end{array}$ \\
\hline Deposit rate & & & $\begin{array}{l}-4.772 \\
{[3.563]}\end{array}$ & & & $\begin{array}{c}-4.904 \\
{[3.136]}\end{array}$ & & & $\begin{array}{l}-1.684 \\
{[2.499]}\end{array}$ \\
\hline Lending rate & & & $\begin{array}{c}7.451 \\
{[6.394]}\end{array}$ & & & $\begin{array}{c}6.784 \\
{[5.436]}\end{array}$ & & & $\begin{array}{c}1.916 \\
{[4.605]}\end{array}$ \\
\hline $\begin{array}{l}\text { Government consumption } \\
\text { growth }\end{array}$ & $\begin{array}{c}0.461 \\
{[0.295]}\end{array}$ & $\begin{array}{c}1.012 * * * \\
{[0.383]}\end{array}$ & $\begin{array}{c}0.710 \\
{[0.464]}\end{array}$ & $\begin{array}{l}0.355^{*} \\
{[0.212]}\end{array}$ & $\begin{array}{c}0.563 * * * \\
{[0.172]}\end{array}$ & $\begin{array}{l}0.280^{*} \\
{[0.153]}\end{array}$ & $\begin{array}{l}0.153 * \\
{[0.087]}\end{array}$ & $\begin{array}{l}0.226^{* *} \\
{[0.100]}\end{array}$ & $\begin{array}{c}0.050 \\
{[0.084]}\end{array}$ \\
\hline Policy rate & $\begin{array}{c}0.064 \\
{[0.215]}\end{array}$ & $\begin{array}{c}0.043 \\
{[0.200]}\end{array}$ & $\begin{array}{l}-0.799 \\
{[0.732]}\end{array}$ & $\begin{array}{c}0.035 \\
{[0.194]}\end{array}$ & $\begin{array}{c}0.096 \\
{[0.173]}\end{array}$ & $\begin{array}{l}-0.542 \\
{[0.595]}\end{array}$ & $\begin{array}{c}0.137 \\
{[0.191]}\end{array}$ & $\begin{array}{c}0.234 \\
{[0.174]}\end{array}$ & $\begin{array}{l}-0.391 \\
{[0.456]}\end{array}$ \\
\hline $\begin{array}{l}\text { Country fixed effects } \\
\text { Observations } \\
\text { Adjusted } \mathrm{R}^{2}\end{array}$ & $\begin{array}{c}\text { Yes } \\
2,335 \\
0.136 \\
\end{array}$ & $\begin{array}{c}\text { Yes } \\
1,793 \\
0.132 \\
\end{array}$ & $\begin{array}{c}\text { Yes } \\
1,103 \\
0.098 \\
\end{array}$ & $\begin{array}{c}\text { Yes } \\
2,334 \\
0.219 \\
\end{array}$ & $\begin{array}{c}\text { Yes } \\
1,790 \\
0.256 \\
\end{array}$ & $\begin{array}{l}\text { Yes } \\
1,104 \\
0.160\end{array}$ & $\begin{array}{c}\text { Yes } \\
2,299 \\
0.313\end{array}$ & $\begin{array}{c}\text { Yes } \\
1,764 \\
0.287\end{array}$ & $\begin{array}{l}\text { Yes } \\
1,101 \\
0.231\end{array}$ \\
\hline \multicolumn{10}{|c|}{ Panel B: Consumption Growth } \\
\hline & \multicolumn{3}{|c|}{ Nowcasting } & \multicolumn{3}{|c|}{1 quarter ahead forecast } & \multicolumn{3}{|c|}{4 quarters ahead forecast } \\
\hline Credit growth & $\begin{array}{c}1.525^{* * *} \\
{[0.490]}\end{array}$ & $\begin{array}{l}1.118^{* *} \\
{[0.492]}\end{array}$ & $\begin{array}{l}0.620^{*} \\
{[0.336]}\end{array}$ & $\begin{array}{c}0.809 * * * \\
{[0.309]}\end{array}$ & $\begin{array}{l}0.534^{*} \\
{[0.310]}\end{array}$ & $\begin{array}{c}0.243 \\
{[0.249]}\end{array}$ & $\begin{array}{c}0.517^{* * *} \\
{[0.184]}\end{array}$ & $\begin{array}{l}0.275^{*} \\
{[0.143]}\end{array}$ & $\begin{array}{c}0.118 \\
{[0.110]}\end{array}$ \\
\hline Stock price & & $\begin{array}{c}0.590 * * * \\
{[0.228]}\end{array}$ & $\begin{array}{c}0.109 \\
{[0.134]}\end{array}$ & & $\begin{array}{c}0.622 * * * \\
{[0.147]}\end{array}$ & $\begin{array}{c}0.229 * * * \\
{[0.088]}\end{array}$ & & $\begin{array}{c}0.532 * * * \\
{[0.080]}\end{array}$ & $\begin{array}{c}0.303 * * * \\
{[0.075]}\end{array}$ \\
\hline House price & & $\begin{array}{c}1.754 * * * \\
{[0.212]}\end{array}$ & $\begin{array}{c}1.575^{* * *} \\
{[0.232]}\end{array}$ & & $\begin{array}{c}1.436 * * * \\
{[0.196]}\end{array}$ & $\begin{array}{c}1.297 * * * \\
{[0.167]}\end{array}$ & & $\begin{array}{c}1.031 * * * \\
{[0.139]}\end{array}$ & $\begin{array}{c}0.876^{* * *} \\
{[0.130]}\end{array}$ \\
\hline Deposit rate & & & $\begin{array}{c}-4.694 * * \\
{[2.317]}\end{array}$ & & & $\begin{array}{c}-4.298 * * \\
{[2.187]}\end{array}$ & & & $\begin{array}{l}-3.343 * \\
{[1.919]}\end{array}$ \\
\hline Lending rate & & & $\begin{array}{c}4.515 \\
{[4.534]}\end{array}$ & & & $\begin{array}{c}4.942 \\
{[4.339]}\end{array}$ & & & $\begin{array}{c}5.122 \\
{[3.735]}\end{array}$ \\
\hline $\begin{array}{l}\text { Government consumption } \\
\text { growth }\end{array}$ & $\begin{array}{c}0.045 \\
{[0.563]}\end{array}$ & $\begin{array}{c}0.190 \\
{[0.309]}\end{array}$ & $\begin{array}{c}0.292 \\
{[0.382]}\end{array}$ & $\begin{array}{c}0.117 \\
{[0.250]}\end{array}$ & $\begin{array}{c}0.316 \\
{[0.219]}\end{array}$ & $\begin{array}{c}0.172 \\
{[0.211]}\end{array}$ & $\begin{array}{l}-0.011 \\
{[0.105]}\end{array}$ & $\begin{array}{c}0.045 \\
{[0.109]}\end{array}$ & $\begin{array}{l}-0.093 \\
{[0.095]}\end{array}$ \\
\hline Policy rate & $\begin{array}{c}0.135 \\
{[0.243]}\end{array}$ & $\begin{array}{l}0.299 * \\
{[0.169]}\end{array}$ & $\begin{array}{c}-0.003 \\
{[0.577]}\end{array}$ & $\begin{array}{c}0.094 \\
{[0.194]}\end{array}$ & $\begin{array}{c}0.169 \\
{[0.153]}\end{array}$ & $\begin{array}{c}-0.144 \\
{[0.549]}\end{array}$ & $\begin{array}{c}0.208 \\
{[0.180]}\end{array}$ & $\begin{array}{c}0.227 \\
{[0.153]}\end{array}$ & $\begin{array}{l}-0.313 \\
{[0.474]}\end{array}$ \\
\hline Country fixed effects & Yes & Yes & Yes & Yes & Yes & Yes & Yes & Yes & Yes \\
\hline Observations & 2,598 & 2,008 & 1,292 & 2,588 & 2,002 & 1,289 & 2,559 & 1,980 & 1,280 \\
\hline Adjusted $\mathrm{R}^{2}$ & 0.190 & 0.332 & 0.384 & 0.304 & 0.487 & 0.572 & 0.451 & 0.620 & 0.742 \\
\hline
\end{tabular}


Table 3. Panel Regression Results: Advanced Economies (cont')

Panel C: Investment Growth

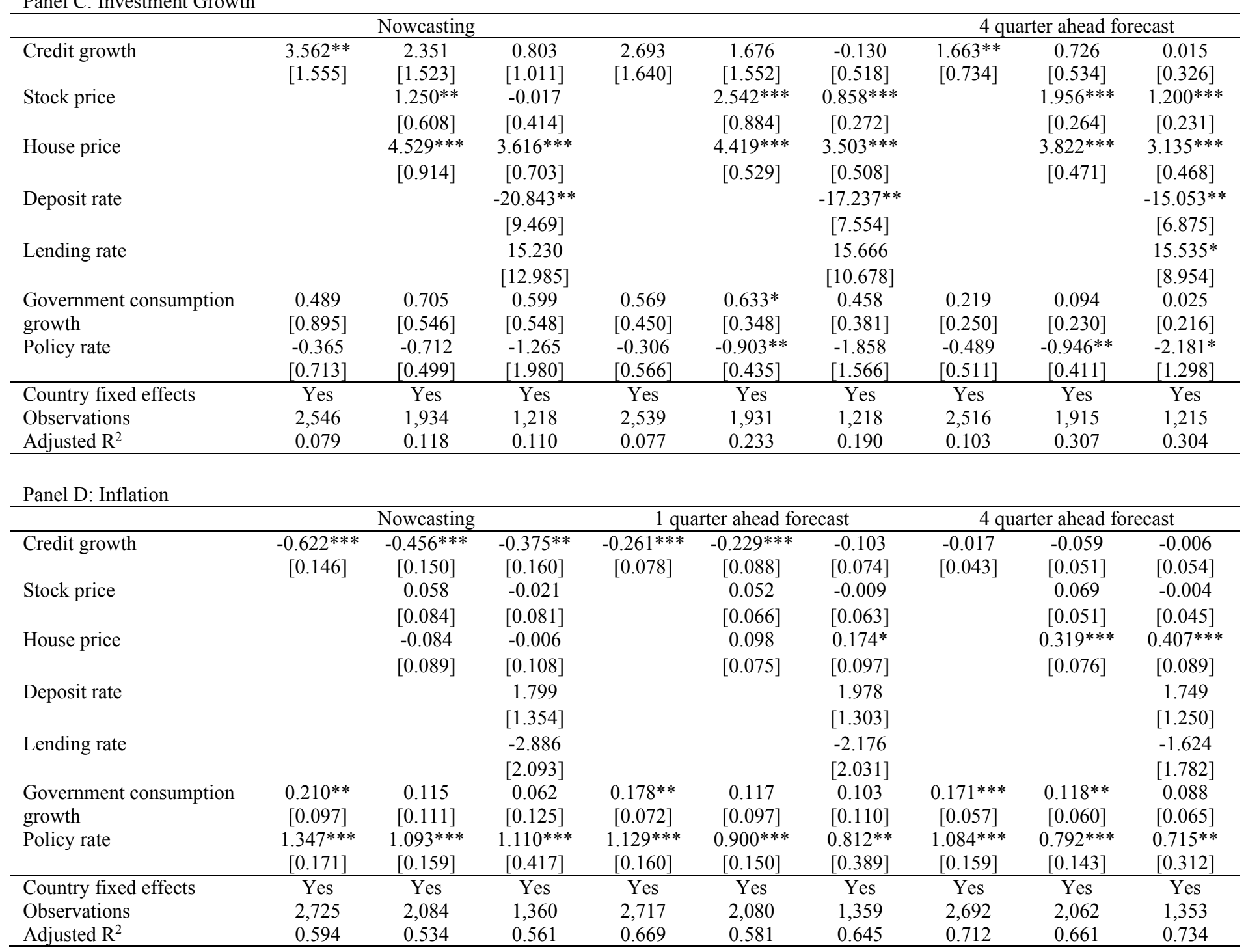


Table 5. Panel Regression Results: Advanced Economies Subsample with Bond Yields

\begin{tabular}{|c|c|c|c|c|c|c|c|c|c|}
\hline \multirow[b]{2}{*}{ Credit growth } & \multicolumn{3}{|c|}{ Nowcasting } & \multicolumn{3}{|c|}{1 quarter ahead forecast } & \multicolumn{3}{|c|}{4 quarter ahead forecast } \\
\hline & $0.920^{*}$ & 0.473 & 0.064 & 0.648 & 0.246 & -0.034 & $0.611^{*}$ & 0.254 & 0.038 \\
\hline & {$[0.512]$} & {$[0.328]$} & {$[0.130]$} & {$[0.440]$} & {$[0.262]$} & {$[0.150]$} & {$[0.357]$} & {$[0.203]$} & {$[0.106]$} \\
\hline \multirow[t]{2}{*}{ Stock price } & & $0.817 * * *$ & $0.750 *$ & & $0.911 * * *$ & $0.681 *$ & & $0.568 * * *$ & $0.405 * *$ \\
\hline & & {$[0.274]$} & {$[0.385]$} & & {$[0.248]$} & {$[0.350]$} & & {$[0.154]$} & {$[0.183]$} \\
\hline \multirow[t]{2}{*}{ House price } & & $2.474 * * *$ & 1.236 & & $2.611 * * *$ & $2.024 *$ & & $2.469 * * *$ & $1.171^{*}$ \\
\hline & & {$[0.417]$} & [1.279] & & {$[0.346]$} & [1.214] & & {$[0.281]$} & {$[0.633]$} \\
\hline \multirow[t]{2}{*}{ Deposit rate } & & & -47.766 & & & -45.895 & & & $-38.719 * *$ \\
\hline & & & {$[35.187]$} & & & {$[30.283]$} & & & {$[17.379]$} \\
\hline \multirow[t]{2}{*}{ Lending rate } & & & -31.437 & & & -27.517 & & & 3.479 \\
\hline & & & {$[45.866]$} & & & {$[37.078]$} & & & [22.492] \\
\hline \multirow[t]{2}{*}{ Sovereign bond yield } & 0.111 & $-0.416^{*}$ & 0.225 & 0.201 & $-0.330^{*}$ & 0.134 & $0.325 * * *$ & -0.087 & $0.287^{*}$ \\
\hline & {$[0.211]$} & {$[0.244]$} & {$[0.496]$} & {$[0.180]$} & {$[0.191]$} & {$[0.405]$} & {$[0.102]$} & [0.109] & {$[0.166]$} \\
\hline \multirow[t]{2}{*}{ Corporate bond yield } & $-0.501^{*}$ & 0.177 & -0.861 & $-0.704 * * *$ & -0.015 & -0.757 & $-0.757 * * *$ & -0.166 & $-0.483 * *$ \\
\hline & [0.288] & {$[0.315]$} & {$[0.658]$} & [0.244] & {$[0.218]$} & {$[0.478]$} & [0.146] & [0.137] & {$[0.238]$} \\
\hline \multirow{2}{*}{$\begin{array}{l}\text { Government consumption } \\
\text { growth }\end{array}$} & $2.295 * * *$ & $2.026 * * *$ & $0.750^{*}$ & 0.567 & 0.211 & 0.855 & $2.295 * * *$ & $2.295 * * *$ & $3.429 * * *$ \\
\hline & {$[0.512]$} & {$[0.486]$} & {$[0.385]$} & [0.367] & [0.302] & {$[0.666]$} & {$[0.512]$} & {$[0.512]$} & {$[0.874]$} \\
\hline \multirow[t]{2}{*}{ Policy rate } & -0.198 & 0.920 & 1.236 & -0.571 & 0.765 & 7.635 & 0.111 & $-0.416^{*}$ & 6.599 \\
\hline & {$[0.211]$} & {$[0.761]$} & {$[1.279]$} & [0.894] & {$[0.712]$} & [5.488] & {$[0.211]$} & {$[0.244]$} & [7.069] \\
\hline Country fixed effects & Yes & Yes & Yes & Yes & Yes & Yes & Yes & Yes & Yes \\
\hline Observations & 444 & 394 & 137 & 438 & 389 & 136 & 444 & 394 & 137 \\
\hline Adjusted $\mathrm{R}^{2}$ & 0.266 & 0.346 & 0.211 & 0.244 & 0.431 & 0.285 & 0.266 & 0.346 & 0.211 \\
\hline
\end{tabular}


Table 4. Panel Regression Results: Advanced Economies Subsample with Bond Yields (cont')

Panel B: Consumption Growth

\begin{tabular}{|c|c|c|c|c|c|c|c|c|c|}
\hline \multirow[b]{2}{*}{ Credit growth } & \multicolumn{3}{|c|}{ Nowcasting } & \multicolumn{3}{|c|}{1 quarter ahead forecast } & \multicolumn{3}{|c|}{4 quarters ahead forecast } \\
\hline & $1.189 * *$ & $0.826^{* *}$ & 0.333 & $0.801 * *$ & $0.514 *$ & 0.182 & $0.485^{*}$ & $0.260 *$ & 0.072 \\
\hline & {$[0.543]$} & [0.399] & {$[0.300]$} & {$[0.385]$} & {$[0.270]$} & {$[0.222]$} & {$[0.248]$} & {$[0.154]$} & {$[0.060]$} \\
\hline \multirow[t]{2}{*}{ Stock price } & & $0.709^{* * *}$ & $0.726 * * *$ & & $0.564 * * *$ & $0.430 * *$ & & $0.304 * * *$ & $0.168^{*}$ \\
\hline & & {$[0.207]$} & {$[0.261]$} & & [0.187] & {$[0.216]$} & & [0.103] & {$[0.092]$} \\
\hline \multirow{2}{*}{ House price } & & $1.729 * * *$ & $0.877^{*}$ & & $1.897 * * *$ & $1.105 * * *$ & & $1.577 * * *$ & $0.433 * *$ \\
\hline & & {$[0.262]$} & {$[0.497]$} & & {$[0.255]$} & [0.389] & & {$[0.214]$} & {$[0.189]$} \\
\hline \multirow[t]{2}{*}{ Deposit rate } & & & -17.409 & & & $-14.099 *$ & & & $-20.092 * * *$ \\
\hline & & & {$[12.403]$} & & & [8.512] & & & {$[6.764]$} \\
\hline \multirow[t]{2}{*}{ Lending rate } & & & 8.750 & & & 19.683 & & & $38.435 * * *$ \\
\hline & & & {$[21.446]$} & & & {$[15.801]$} & & & {$[11.314]$} \\
\hline \multirow[t]{2}{*}{ Sovereign bond yield } & -0.089 & $-0.418 * * *$ & -0.564 & -0.090 & $-0.347 * *$ & $-0.347 * *$ & 0.048 & -0.110 & -0.012 \\
\hline & {$[0.115]$} & {$[0.161]$} & {$[0.342]$} & {$[0.096]$} & {$[0.144]$} & [0.144] & {$[0.064]$} & {$[0.100]$} & {$[0.072]$} \\
\hline \multirow[t]{2}{*}{ Corporate bond yield } & $-0.402 * *$ & -0.051 & 0.090 & $-0.263 * *$ & 0.035 & 0.035 & $-0.361 * * *$ & $-0.196^{*}$ & -0.068 \\
\hline & [0.189] & {$[0.231]$} & {$[0.416]$} & [0.116] & {$[0.140]$} & {$[0.140]$} & {$[0.091]$} & {$[0.115]$} & {$[0.105]$} \\
\hline \multirow{4}{*}{$\begin{array}{l}\text { Government consumption } \\
\text { growth } \\
\text { Policy rate }\end{array}$} & 0.126 & -0.030 & 0.263 & 0.133 & -0.069 & -0.069 & $0.481 *$ & 0.306 & -0.038 \\
\hline & {$[0.426]$} & {$[0.409]$} & {$[0.565]$} & {$[0.316]$} & {$[0.258]$} & {$[0.258]$} & {$[0.255]$} & {$[0.204]$} & {$[0.187]$} \\
\hline & -0.290 & $-0.418 * * *$ & 1.927 & -0.732 & -0.092 & -0.092 & $-1.749 * *$ & $-1.390 * *$ & -2.045 \\
\hline & {$[0.581]$} & {$[0.161]$} & {$[3.730]$} & {$[0.609]$} & {$[0.532]$} & {$[0.532]$} & {$[0.724]$} & {$[0.653]$} & [1.896] \\
\hline Country fixed effects & Yes & Yes & Yes & Yes & Yes & Yes & Yes & Yes & Yes \\
\hline Observations & 504 & 451 & 189 & 498 & 448 & 188 & 480 & 433 & 182 \\
\hline Adjusted $\mathrm{R}^{2}$ & 0.232 & 0.306 & 0.211 & 0.261 & 0.306 & 0.211 & 0.332 & 0.495 & 0.646 \\
\hline
\end{tabular}


Table 4. Panel Regression Results: Advanced Economies Subsample with Bond Yields (cont')

\begin{tabular}{|c|c|c|c|c|c|c|c|c|c|}
\hline \multirow{3}{*}{ Credit growth } & \multicolumn{3}{|c|}{ Nowcasting } & \multicolumn{3}{|c|}{1 quarter ahead forecast } & \multicolumn{3}{|c|}{4 quarters ahead forecast } \\
\hline & $2.253^{*}$ & 1.380 & 0.595 & $1.468 *$ & 0.735 & 0.342 & $1.254^{*}$ & 0.619 & 0.182 \\
\hline & {$[1.272]$} & {$[1.146]$} & {$[1.123]$} & {$[0.778]$} & {$[0.607]$} & {$[0.491]$} & {$[0.734]$} & {$[0.512]$} & {$[0.390]$} \\
\hline \multirow[t]{2}{*}{ Stock price } & & $2.058 * * *$ & 0.789 & & $2.346 * * *$ & $1.280 * *$ & & $1.895 * * *$ & $0.889 * *$ \\
\hline & & {$[0.528]$} & {$[0.524]$} & & {$[0.468]$} & {$[0.558]$} & & {$[0.394]$} & {$[0.359]$} \\
\hline \multirow[t]{2}{*}{ House price } & & $6.418 * * *$ & 2.174 & & $5.769 * * *$ & $4.841 * * *$ & & $5.982 * * *$ & $3.886^{* * *}$ \\
\hline & & {$[0.984]$} & [1.601] & & {$[0.863]$} & {$[1.612]$} & & {$[0.723]$} & {$[1.070]$} \\
\hline \multirow[t]{2}{*}{ Deposit rate } & & & -62.549 & & & -59.311 & & & $-105.315 * * *$ \\
\hline & & & {$[40.315]$} & & & {$[40.740]$} & & & {$[32.577]$} \\
\hline \multirow[t]{2}{*}{ Lending rate } & & & 29.353 & & & -15.184 & & & -15.997 \\
\hline & & & {$[63.805]$} & & & {$[59.528]$} & & & {$[50.944]$} \\
\hline \multirow[t]{2}{*}{ Sovereign bond yield } & -0.005 & $-1.762 * * *$ & $-1.420 * *$ & $0.748 * *$ & $-0.738 * *$ & -0.527 & $1.018^{* * *}$ & -0.227 & -0.014 \\
\hline & {$[0.367]$} & {$[0.467]$} & {$[0.554]$} & {$[0.334]$} & {$[0.341]$} & {$[0.632]$} & {$[0.225]$} & {$[0.258]$} & {$[0.431]$} \\
\hline \multirow[t]{2}{*}{ Corporate bond yield } & 0.033 & $1.970 * * *$ & 1.262 & $-0.935^{*}$ & $0.821 * *$ & 0.791 & $-1.715^{* * *}$ & -0.119 & -0.094 \\
\hline & {$[0.497]$} & {$[0.495]$} & {$[0.793]$} & {$[0.490]$} & {$[0.408]$} & {$[0.797]$} & [0.342] & {$[0.320]$} & [0.589] \\
\hline \multirow{2}{*}{$\begin{array}{l}\text { Government consumption } \\
\text { growth }\end{array}$} & -2.432 & $-3.390 * *$ & -2.249 & -0.641 & -1.529 & -0.766 & 0.758 & -0.078 & -0.099 \\
\hline & [1.601] & {$[1.474]$} & {$[2.464]$} & {$[1.078]$} & {$[1.023]$} & {$[1.581]$} & {$[0.801]$} & {$[0.666]$} & [1.133] \\
\hline \multirow[t]{2}{*}{ Policy rate } & -0.845 & 0.820 & 3.820 & -2.703 & -1.535 & 8.420 & $-7.600 * * *$ & $-6.244 * * *$ & 7.937 \\
\hline & [2.029] & [2.035] & {$[9.682]$} & {$[1.880]$} & {$[1.769]$} & {$[9.333]$} & [2.049] & [1.882] & {$[7.465]$} \\
\hline Country fixed effects & Yes & Yes & Yes & Yes & Yes & Yes & Yes & Yes & Yes \\
\hline Observations & 501 & 448 & 186 & 496 & 446 & 186 & 481 & 434 & 183 \\
\hline Adjusted $\mathrm{R}^{2}$ & 0.152 & 0.252 & 0.149 & 0.199 & 0.252 & 0.149 & 0.259 & 0.484 & 0.485 \\
\hline
\end{tabular}


Table 4. Panel Regression Results: Advanced Economies Subsample with Bond Yields (cont')

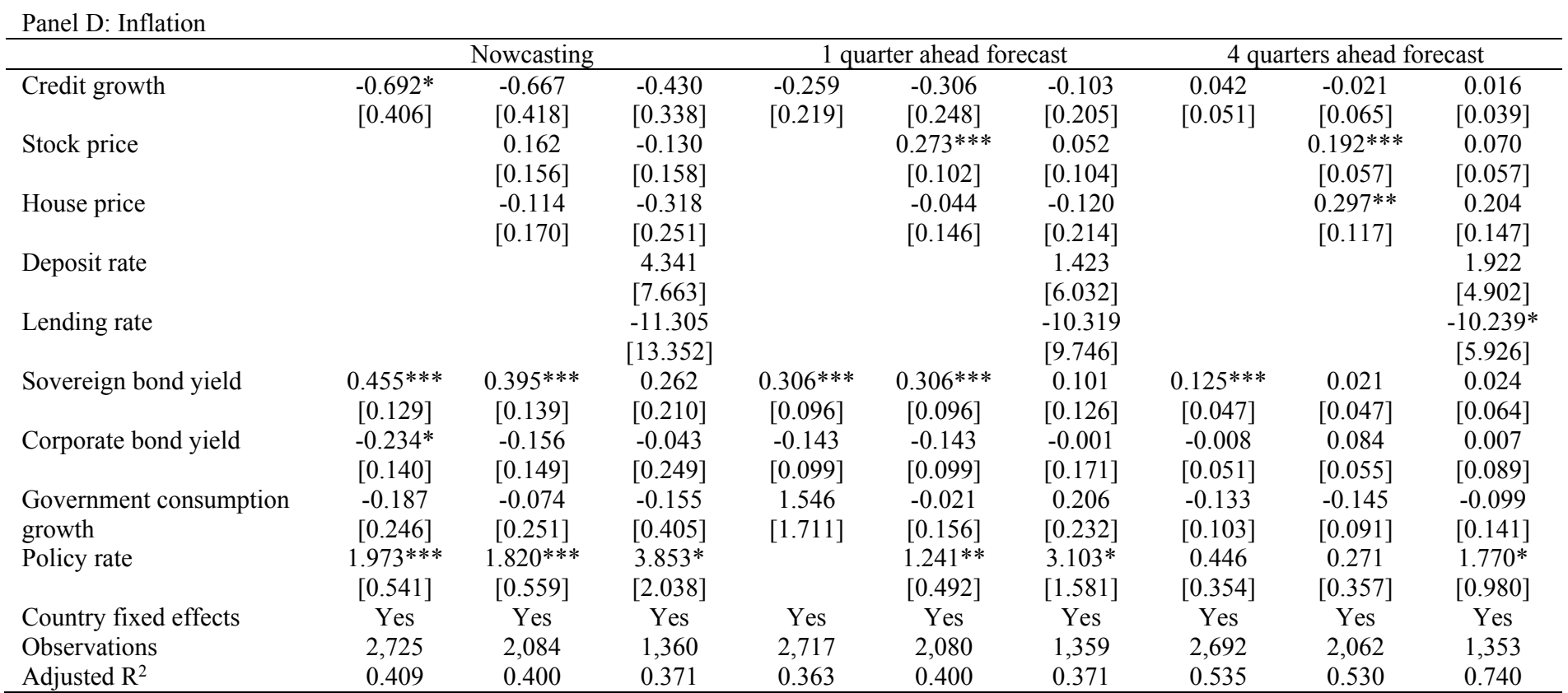


Table 6. Panel Regression Results: Emerging Markets

\begin{tabular}{|c|c|c|c|c|c|c|c|c|c|}
\hline \multirow[b]{2}{*}{ Credit growth } & \multicolumn{3}{|c|}{ Nowcasting } & \multicolumn{3}{|c|}{1 quarter ahead forecast } & \multicolumn{3}{|c|}{4 quarters ahead forecast } \\
\hline & $\begin{array}{c}4.539 * * * \\
{[0.634]}\end{array}$ & $\begin{array}{c}5.390 * * * \\
{[0.936]}\end{array}$ & $\begin{array}{c}5.073 * * * \\
{[0.994]}\end{array}$ & $\begin{array}{c}2.398 * * * \\
{[0.538]}\end{array}$ & $\begin{array}{c}3.568 * * * \\
{[0.792]}\end{array}$ & $\begin{array}{c}3.224 * * * \\
{[0.805]}\end{array}$ & $\begin{array}{c}0.552 \\
{[0.417]}\end{array}$ & $\begin{array}{c}0.815 \\
{[0.663]}\end{array}$ & $\begin{array}{c}1.022 \\
{[0.674]}\end{array}$ \\
\hline Stock price & & $1.767 * * *$ & $1.638 * * *$ & & $2.142 * * *$ & $2.122 * * *$ & & $1.192 * * *$ & $1.171 * * *$ \\
\hline & & {$[0.538]$} & {$[0.561]$} & & {$[0.450]$} & {$[0.475]$} & & {$[0.324]$} & {$[0.326]$} \\
\hline House price & & $\begin{array}{c}0.532 \\
{[0.561]}\end{array}$ & $\begin{array}{c}0.023 \\
{[0.459]}\end{array}$ & & $\begin{array}{c}-4.173 * * * \\
{[1.316]}\end{array}$ & $\begin{array}{l}-1.652 \\
{[3.833]}\end{array}$ & & $\begin{array}{c}-5.360 * * * \\
{[1.512]}\end{array}$ & $\begin{array}{c}1.411 \\
{[4.626]}\end{array}$ \\
\hline Deposit rate & & & $\begin{array}{c}-254.799 * * \\
{[125.273]}\end{array}$ & & & $\begin{array}{l}-0.156 \\
{[0.352]}\end{array}$ & & & $\begin{array}{c}0.051 \\
{[0.348]}\end{array}$ \\
\hline Lending rate & & & $\begin{array}{c}26.840 \\
{[26.495]}\end{array}$ & & & $\begin{array}{l}-190.540 \\
{[133.586]}\end{array}$ & & & $\begin{array}{c}-49.181 \\
{[160.038]}\end{array}$ \\
\hline $\begin{array}{l}\text { Government consumption } \\
\text { growth }\end{array}$ & $\begin{array}{c}1.945 * * * \\
{[0.583]}\end{array}$ & $\begin{array}{l}1.948^{*} \\
{[1.122]}\end{array}$ & $\begin{array}{c}2.816 * * * \\
{[1.043]}\end{array}$ & $\begin{array}{c}1.354 * * * \\
{[0.481]}\end{array}$ & $\begin{array}{c}0.634 \\
{[0.955]}\end{array}$ & $\begin{array}{l}1.632 * * \\
{[0.732]}\end{array}$ & $\begin{array}{c}0.388 \\
{[0.325]}\end{array}$ & $\begin{array}{c}0.259 \\
{[0.444]}\end{array}$ & $\begin{array}{l}0.633 \\
{[0.393]}\end{array}$ \\
\hline Policy rate & $\begin{array}{c}-1.725 * * * \\
{[0.496]} \\
\end{array}$ & $\begin{array}{c}-2.809^{* * * *} \\
{[0.578]} \\
\end{array}$ & $\begin{array}{c}-0.917 \\
{[1.275]}\end{array}$ & $\begin{array}{c}-2.085 * * * \\
{[0.626]} \\
\end{array}$ & $\begin{array}{c}-2.930 * * * \\
{[0.567]} \\
\end{array}$ & $\begin{array}{l}-1.555 \\
{[1.109]}\end{array}$ & $\begin{array}{c}-1.919 * * * \\
{[0.621]} \\
\end{array}$ & $\begin{array}{c}-2.761 * * * \\
{[0.616]} \\
\end{array}$ & $\begin{array}{c}-4.186^{* *} \\
{[1.804]} \\
\end{array}$ \\
\hline $\begin{array}{l}\text { Country fixed effects } \\
\text { Observations } \\
\text { Adjusted } \mathrm{R}^{2}\end{array}$ & $\begin{array}{c}\text { Yes } \\
1,043 \\
0.107\end{array}$ & $\begin{array}{c}\text { Yes } \\
468 \\
0.143\end{array}$ & $\begin{array}{c}\text { Yes } \\
444 \\
0.153\end{array}$ & $\begin{array}{c}\text { Yes } \\
1,032 \\
0.103\end{array}$ & $\begin{array}{c}\text { Yes } \\
464 \\
0.218\end{array}$ & $\begin{array}{c}\text { Yes } \\
440 \\
0.234\end{array}$ & $\begin{array}{l}\text { Yes } \\
973 \\
0.155\end{array}$ & $\begin{array}{c}\text { Yes } \\
441 \\
0.277\end{array}$ & $\begin{array}{c}\text { Yes } \\
419 \\
0.292\end{array}$ \\
\hline \multicolumn{10}{|c|}{ Panel B: Consumption Growth } \\
\hline & \multicolumn{3}{|c|}{ Nowcasting } & \multicolumn{3}{|c|}{1 quarter ahead forecast } & \multicolumn{3}{|c|}{4 quarters ahead forecast } \\
\hline Credit growth & $\begin{array}{c}-10.123 * * \\
{[4.668]}\end{array}$ & $\begin{array}{c}-2.411 * * * \\
{[0.527]}\end{array}$ & $\begin{array}{c}-2.288 * * * \\
{[0.544]}\end{array}$ & $\begin{array}{c}-4.665 * * \\
{[2.239]}\end{array}$ & $\begin{array}{l}-0.284 \\
{[0.538]}\end{array}$ & $\begin{array}{l}-0.034 \\
{[0.576]}\end{array}$ & $\begin{array}{l}-1.527 \\
{[1.116]}\end{array}$ & $\begin{array}{c}1.208 * * * \\
0.382]\end{array}$ & $\begin{array}{c}1.515^{* * *} \\
{[0.482]}\end{array}$ \\
\hline Stock price & & $\begin{array}{l}-0.081 \\
{[0.267]}\end{array}$ & $\begin{array}{l}-0.036 \\
{[0.289]}\end{array}$ & & $\begin{array}{c}0.103 \\
{[0.234]}\end{array}$ & $\begin{array}{c}0.088 \\
{[0.241]}\end{array}$ & & $\begin{array}{c}0.116 \\
{[0.246]}\end{array}$ & $\begin{array}{c}0.092 \\
{[0.262]}\end{array}$ \\
\hline House price & & $\begin{array}{c}-1.334^{* *} \\
{[0.650]}\end{array}$ & $\begin{array}{l}-1.288^{*} \\
{[0.708]}\end{array}$ & & $\begin{array}{l}-1.259^{*} \\
{[0.701]}\end{array}$ & $\begin{array}{l}-1.251^{*} \\
{[0.729]}\end{array}$ & & $\begin{array}{c}-0.661 \\
{[0.406]}\end{array}$ & $\begin{array}{l}-0.570 \\
{[0.379]}\end{array}$ \\
\hline Deposit rate & & & $\begin{array}{c}95.768 \\
{[125.152]}\end{array}$ & & & $\begin{array}{c}209.292 \\
{[160.210]}\end{array}$ & & & $\begin{array}{c}306.391 \\
{[247.152]}\end{array}$ \\
\hline Lending rate & & & $\begin{array}{l}-36.362 \\
{[24.489]}\end{array}$ & & & $\begin{array}{l}-39.737 \\
{[29.972]}\end{array}$ & & & $\begin{array}{l}-24.131 \\
{[32.522]}\end{array}$ \\
\hline $\begin{array}{l}\text { Government consumption } \\
\text { growth }\end{array}$ & $\begin{array}{l}-0.068 \\
{[1.736]}\end{array}$ & $\begin{array}{c}1.584 \\
{[1.746]}\end{array}$ & $\begin{array}{c}1.398 \\
{[1.973]}\end{array}$ & $\begin{array}{l}2.529^{* *} \\
{[1.202]}\end{array}$ & $\begin{array}{c}0.640 \\
{[0.706]}\end{array}$ & $\begin{array}{c}0.528 \\
{[0.806]}\end{array}$ & $\begin{array}{l}2.271^{* *} \\
{[0.885]}\end{array}$ & $\begin{array}{c}0.567 \\
{[0.348]}\end{array}$ & $\begin{array}{c}0.616 \\
{[0.387]}\end{array}$ \\
\hline Policy rate & $\begin{array}{c}-4.128 * * * \\
{[1.398]}\end{array}$ & $\begin{array}{c}-2.223 * * * \\
{[0.670]}\end{array}$ & $\begin{array}{c}0.300 \\
{[2.104]}\end{array}$ & $\begin{array}{c}-4.288 * * * \\
{[1.419]}\end{array}$ & $\begin{array}{c}-1.862 * * \\
{[0.753]}\end{array}$ & $\begin{array}{l}-1.123 \\
{[1.447]}\end{array}$ & $\begin{array}{c}-3.543 * * * \\
{[1.027]}\end{array}$ & $\begin{array}{c}-1.551 * * * \\
{[0.590]}\end{array}$ & $\begin{array}{l}-1.820 \\
{[1.365]}\end{array}$ \\
\hline Country fixed effects & Yes & Yes & Yes & Yes & Yes & Yes & Yes & Yes & Yes \\
\hline Observations & 1,527 & 639 & 614 & 1,502 & 634 & 610 & 1,425 & 611 & 588 \\
\hline Adjusted $\mathrm{R}^{2}$ & 0.184 & 0.071 & 0.075 & 0.214 & 0.113 & 0.123 & 0.287 & 0.182 & 0.189 \\
\hline
\end{tabular}


Table 5. Panel Regression Results: Emerging Markets (cont')

Panel C: Investment Growth

\begin{tabular}{|c|c|c|c|c|c|c|c|c|c|}
\hline \multirow{2}{*}{ Credit growth } & \multicolumn{3}{|c|}{ Nowcasting } & \multicolumn{3}{|c|}{1 quarter ahead forecast } & \multicolumn{3}{|c|}{4 quarters ahead forecast } \\
\hline & $13.229 * * *$ & $7.069 * * *$ & $5.338^{*}$ & $6.575 * * *$ & $4.484 * *$ & 3.114 & $2.584 * *$ & 0.590 & -0.356 \\
\hline & {$[1.878]$} & {$[2.424]$} & {$[2.920]$} & {$[1.375]$} & {$[1.995]$} & {$[2.068]$} & [1.099] & {$[1.556]$} & {$[1.710]$} \\
\hline \multirow[t]{2}{*}{ Stock price } & & $2.394 *$ & $2.438^{*}$ & & $2.957 * * *$ & $3.109 * * *$ & & $2.343 * * *$ & $2.440 * * *$ \\
\hline & & {$[1.363]$} & [1.392] & & {$[1.005]$} & {$[1.080]$} & & {$[0.718]$} & {$[0.716]$} \\
\hline \multirow[t]{2}{*}{ House price } & & $2.984 * *$ & $2.642 *$ & & $2.095^{*}$ & 2.087 & & 1.239 & 1.296 \\
\hline & & {$[1.338]$} & {$[1.452]$} & & {$[1.192]$} & {$[1.280]$} & & {$[0.849]$} & [0.891] \\
\hline \multirow[t]{2}{*}{ Deposit rate } & & & $-1,019.597 * * *$ & & & $-668.876^{* *}$ & & & $-616.427 * *$ \\
\hline & & & {$[296.588]$} & & & {$[291.995]$} & & & {$[262.830]$} \\
\hline \multirow[t]{2}{*}{ Lending rate } & & & 44.151 & & & 46.204 & & & $99.554 *$ \\
\hline & & & [68.932] & & & [63.868] & & & {$[56.346]$} \\
\hline Government consumption & $3.970^{*}$ & -1.812 & -0.755 & $2.696^{* *}$ & -0.573 & 0.201 & $2.415 * * *$ & 1.282 & $1.969 *$ \\
\hline growth & {$[2.040]$} & [3.032] & [3.513] & {$[1.281]$} & {$[1.504]$} & {$[1.672]$} & {$[0.920]$} & {$[0.967]$} & {$[1.013]$} \\
\hline \multirow[t]{2}{*}{ Policy rate } & $-7.568 * * *$ & $-11.091 * * *$ & 0.511 & $-7.097 * * *$ & $-11.730 * * *$ & -4.832 & $-6.417 * * *$ & $-11.138 * * *$ & $-7.149 * *$ \\
\hline & [1.769] & {$[2.328]$} & {$[4.740]$} & {$[1.574]$} & {$[2.129]$} & [5.419] & {$[1.422]$} & {$[2.014]$} & {$[2.874]$} \\
\hline Country fixed effects & Yes & Yes & Yes & Yes & Yes & Yes & Yes & Yes & Yes \\
\hline Observations & 1,491 & 639 & 614 & 1,467 & 634 & 610 & 1,393 & 611 & 588 \\
\hline Adjusted $\mathrm{R}^{2}$ & 0.126 & 0.111 & 0.123 & 0.123 & 0.219 & 0.230 & 0.177 & 0.341 & 0.362 \\
\hline \multicolumn{10}{|l|}{ Panel D: Inflation } \\
\hline & \multicolumn{3}{|c|}{ Nowcasting } & \multicolumn{3}{|c|}{1 quarter ahead forecast } & \multicolumn{3}{|c|}{4 quarters ahead forecast } \\
\hline Credit growth & $\begin{array}{c}-10.123^{* *} \\
{[4.668]}\end{array}$ & $\begin{array}{c}-2.411 * * * \\
{[0.527]}\end{array}$ & $\begin{array}{c}-2.288^{* * *} \\
{[0.544]}\end{array}$ & $\begin{array}{c}-4.665^{* *} \\
{[2.239]}\end{array}$ & $\begin{array}{c}-0.284 \\
{[0.538]}\end{array}$ & $\begin{array}{c}-0.034 \\
{[0.576]}\end{array}$ & $\begin{array}{c}-1.527 \\
{[1.116]}\end{array}$ & $\begin{array}{c}1.208 * * * \\
{[0.382]}\end{array}$ & $\begin{array}{c}1.515^{* * * *} \\
{[0.482]}\end{array}$ \\
\hline \multicolumn{10}{|l|}{ Stock price } \\
\hline \multirow[t]{2}{*}{ House price } & & $-3.152 * * *$ & $-2.678 * * *$ & & $-2.764 * * *$ & $-2.291 * *$ & & $-2.181 * *$ & $-1.946^{*}$ \\
\hline & & {$[0.938]$} & [0.973] & & {$[0.945]$} & {$[1.003]$} & & {$[0.971]$} & {$[1.023]$} \\
\hline \multirow[t]{2}{*}{ Deposit rate } & & & $-1.288^{*}$ & & & $-1.251^{*}$ & & & -0.570 \\
\hline & & & {$[0.708]$} & & & {$[0.729]$} & & & {$[0.379]$} \\
\hline \multirow[t]{2}{*}{ Lending rate } & & & 95.768 & & & 209.292 & & & 306.391 \\
\hline & & & {$[125.152]$} & & & {$[160.210]$} & & & {$[247.152]$} \\
\hline \multirow{4}{*}{$\begin{array}{l}\text { Government consumption } \\
\text { growth } \\
\text { Policy rate }\end{array}$} & 7.865 & 0.142 & 0.376 & 5.279 & 0.565 & 0.760 & 1.888 & 0.262 & 0.446 \\
\hline & {$[5.621]$} & {$[0.528]$} & {$[0.608]$} & {$[3.738]$} & {$[0.606]$} & {$[0.720]$} & [1.469] & {$[0.243]$} & {$[0.290]$} \\
\hline & $6.532 * * *$ & $4.234 * * *$ & $4.661^{*}$ & $7.874 * * *$ & $4.357 * * *$ & 3.689 & $9.361 * * *$ & $3.920 * *$ & 1.627 \\
\hline & {$[1.843]$} & {$[1.320]$} & {$[2.522]$} & {$[2.442]$} & [1.487] & [2.325] & {$[2.815]$} & {$[1.517]$} & {$[1.554]$} \\
\hline Country fixed effects & Yes & Yes & Yes & Yes & Yes & Yes & Yes & Yes & Yes \\
\hline Observations & 1,662 & 662 & 628 & 1,638 & 658 & 627 & 1,561 & 636 & 606 \\
\hline Adjusted R ${ }^{2}$ & 0.583 & 0.572 & 0.578 & 0.568 & 0.516 & 0.528 & 0.571 & 0.480 & 0.500 \\
\hline
\end{tabular}


Table 7. Panel Regression Results: Low-Income Countries

Panel A: GDP Growth

\begin{tabular}{lccc}
\hline & Nowcasting & $\begin{array}{c}1 \text { quarter ahead } \\
\text { forecast }\end{array}$ & $\begin{array}{c}4 \text { quarters ahead } \\
\text { forecast }\end{array}$ \\
\hline Credit growth & $6.745^{* *}$ & $6.921^{* * *}$ & $2.143^{* *}$ \\
& {$[3.070]$} & {$[1.813]$} & {$[0.845]$} \\
Government consumption & 1.303 & 0.020 & $0.571^{*}$ \\
growth & {$[1.112]$} & {$[0.536]$} & {$[0.324]$} \\
Policy rate & $-5.414^{* *}$ & $-6.052^{* *}$ & $-3.135^{*}$ \\
& {$[2.148]$} & {$[2.331]$} & {$[1.654]$} \\
\hline Country fixed effects & Yes & Yes & Yes \\
Observations & 109 & 112 & 109 \\
$\mathrm{R}^{2}$ & 0.067 & 0.213 & 0.125 \\
\hline
\end{tabular}

Panel B: Consumption Growth

\begin{tabular}{lccc}
\hline & Nowcasting & $\begin{array}{c}1 \text { quarter ahead } \\
\text { forecast }\end{array}$ & $\begin{array}{c}4 \text { quarters ahead } \\
\text { forecast }\end{array}$ \\
\hline Credit growth & $9.386^{* * *}$ & $4.335^{*}$ & $2.630^{* *}$ \\
& {$[3.490]$} & {$[2.340]$} & {$[1.075]$} \\
Government consumption & 1.036 & 0.144 & -0.090 \\
growth & {$[2.699]$} & {$[1.329]$} & {$[0.277]$} \\
Policy rate & 0.229 & -0.783 & -1.223 \\
& {$[2.881]$} & {$[1.415]$} & {$[1.024]$} \\
\hline Country fixed effects & Yes & Yes & Yes \\
Observations & 149 & 147 & 141 \\
$\mathrm{R}^{2}$ & 0.196 & 0.338 & 0.463 \\
\hline
\end{tabular}

Panel C: Investment Growth

\begin{tabular}{ccc}
\hline Nowcasting & $\begin{array}{c}1 \text { quarter ahead } \\
\text { forecast }\end{array}$ & $\begin{array}{c}4 \text { quarters ahead } \\
\text { forecast }\end{array}$ \\
\hline $34.041^{* * *}$ & 9.447 & 6.636 \\
{$[11.249]$} & {$[6.949]$} & {$[5.725]$} \\
$-10.776^{*}$ & 0.026 & -1.314 \\
{$[6.405]$} & {$[2.958]$} & {$[1.575]$} \\
$-8.176^{*}$ & -3.202 & -5.550 \\
{$[4.519]$} & {$[2.982]$} & {$[3.746]$} \\
\hline Yes & Yes & Yes \\
149 & 147 & 141 \\
0.182 & 0.369 & 0.058 \\
\hline
\end{tabular}

Panel D: Inflation

\begin{tabular}{ccc}
\hline Nowcasting & $\begin{array}{c}1 \text { quarter ahead } \\
\text { forecast }\end{array}$ & $\begin{array}{c}4 \text { quarters ahead } \\
\text { forecast }\end{array}$ \\
\hline$-4.213^{* *}$ & -0.891 & 1.163 \\
{$[1.852]$} & {$[1.360]$} & {$[1.412]$} \\
0.995 & 0.644 & 0.470 \\
{$[0.671]$} & {$[0.507]$} & {$[0.413]$} \\
1.236 & 0.938 & -0.592 \\
{$[0.762]$} & {$[0.736]$} & {$[0.406]$} \\
\hline Yes & Yes & Yes \\
157 & 155 & 149 \\
0.299 & 0.181 & 0.142 \\
\hline
\end{tabular}

Notes for Table 2 to 6: This table reports results of an ordinary least squares (OLS) fixed effects (FE) estimate. The sample period is 1980 Q1 to 2013 Q4. The dependent variable is annualized GDP, consumption, investment growth, or inflation. The right-hand side includes the lagged lefthand side variable. We use Akaike Information Criterion (AIC) to determine the lag length in each specification. Newey-West standard errors are in bracket. *,**, and *** indicate statistical significance at the 1 percent, 5 percent, and 10 percent level, respectively. 
Table 8. Comparing Panel and Individual Country Model Performance: Advanced Economies

Panel A: In sample

\begin{tabular}{|c|c|c|c|c|c|c|}
\hline \multirow[t]{2}{*}{ Country } & \multicolumn{3}{|c|}{ Model 1 (AR) } & \multicolumn{3}{|c|}{ Model 2 (AR and Credit) } \\
\hline & $\begin{array}{l}\text { Individual } \\
\text { RMSE }\end{array}$ & $\begin{array}{l}\text { Panel } \\
\text { RMSE }\end{array}$ & $\begin{array}{c}1 \text { if Panel } \\
\text { outperforms } \\
\text { Individual }\end{array}$ & $\begin{array}{l}\text { Individual } \\
\text { RMSE }\end{array}$ & $\begin{array}{l}\text { Panel } \\
\text { RMSE }\end{array}$ & $\begin{array}{c}1 \text { if Panel } \\
\text { outperforms } \\
\text { Individual }\end{array}$ \\
\hline United States & 3.328 & 3.806 & 0 & 2.850 & 3.648 & 0 \\
\hline United Kingdom & 3.158 & 3.833 & 0 & 2.781 & 3.659 & 0 \\
\hline Austria & 5.400 & 5.573 & 0 & 4.732 & 5.315 & 0 \\
\hline Belgium & 4.091 & 4.407 & 0 & 3.939 & 4.410 & 0 \\
\hline Denmark & 5.172 & 5.408 & 0 & 5.061 & 5.872 & 0 \\
\hline France & 3.171 & 3.350 & 0 & 2.501 & 2.919 & 0 \\
\hline Germany & 2.955 & 3.525 & 0 & 2.312 & 3.358 & 0 \\
\hline Italy & 4.478 & 5.134 & 0 & 4.192 & 5.146 & 0 \\
\hline Netherlands & 4.548 & 4.601 & 0 & 4.642 & 4.849 & 0 \\
\hline Norway & 9.349 & 9.726 & 0 & 8.300 & 9.654 & 0 \\
\hline Sweden & 5.445 & 5.031 & 1 & 2.477 & 3.635 & 0 \\
\hline Switzerland & 5.064 & 5.263 & 0 & 4.583 & 5.090 & 0 \\
\hline Canada & 4.055 & 4.327 & 0 & 2.696 & 3.629 & 0 \\
\hline Japan & 5.117 & 5.303 & 0 & 4.961 & 5.179 & 0 \\
\hline Finland & 6.987 & 7.178 & 0 & 6.827 & 7.135 & 0 \\
\hline Greece & 4.250 & 6.075 & 0 & 3.789 & 5.981 & 0 \\
\hline Iceland & 8.201 & 10.094 & 0 & 6.685 & 10.207 & 0 \\
\hline Malta & 8.366 & 9.767 & 0 & 7.873 & 9.803 & 0 \\
\hline Portugal & 5.842 & 6.156 & 0 & 5.275 & 6.003 & 0 \\
\hline Spain & 4.183 & 4.305 & 0 & 3.876 & 4.079 & 0 \\
\hline New Zealand & 6.022 & 6.588 & 0 & 5.267 & 6.377 & 0 \\
\hline Cyprus & 4.541 & 5.894 & 0 & 4.169 & 6.470 & 0 \\
\hline Israel & 9.566 & 9.602 & 0 & 7.125 & 8.038 & 0 \\
\hline Korea of & 7.194 & 7.726 & 0 & 7.037 & 7.604 & 0 \\
\hline Slovak Republic & 8.611 & 9.112 & 0 & 6.645 & 8.214 & 0 \\
\hline Latvia & 9.047 & 10.487 & 0 & 7.674 & 9.924 & 0 \\
\hline Slovenia & 3.716 & 6.871 & 0 & 3.160 & 7.421 & 0 \\
\hline \multicolumn{3}{|c|}{ Panel model outperforms (\%) } & 4 & & & 0 \\
\hline \multicolumn{7}{|c|}{$\begin{array}{l}\text { Notes: This table shows the in-sample forecasting errors (RMSE) of } 4 \text { quarters ahead GDP growth from } \\
\text { an individual country model and a panel model. Model } 1 \text { is an AR model with lags chosen by AIC. } \\
\text { Model } 2 \text { adds credit growth and policy variables to the AR model. The bottom row is the percentage of } \\
\text { cases in which the panel model outperforms the individual country model. }{ }^{*}, * * \text {, and } * * * \text { indicate } \\
\text { statistical significance at the } 1 \text { percent, } 5 \text { percent, and } 10 \text { percent level, respectively. }\end{array}$} \\
\hline
\end{tabular}


Table 7. Comparing Panel and Individual Country Model Performance: Advanced Economies (cont')

Panel B: Out of sample

\begin{tabular}{|c|c|c|c|c|c|c|}
\hline \multirow[t]{2}{*}{ Country } & \multicolumn{3}{|c|}{ Model 1 (AR) } & \multicolumn{3}{|c|}{ Model 2 (AR and Credit) } \\
\hline & $\begin{array}{l}\text { Individual } \\
\text { RMSE }\end{array}$ & $\begin{array}{l}\text { Panel } \\
\text { RMSE }\end{array}$ & $\begin{array}{c}1 \text { if Panel } \\
\text { outperforms } \\
\text { Individual }\end{array}$ & $\begin{array}{l}\text { Individual } \\
\text { RMSE }\end{array}$ & $\begin{array}{l}\text { Panel } \\
\text { RMSE }\end{array}$ & $\begin{array}{c}1 \text { if Panel } \\
\text { outperforms } \\
\text { Individual }\end{array}$ \\
\hline United States & 2.849 & 2.711 & 1 & 3.515 & 2.683 & 1 \\
\hline United Kingdom & 2.982 & 3.021 & 0 & 2.762 & 2.879 & 0 \\
\hline Austria & 3.848 & 3.452 & 1 & 3.562 & 3.337 & 1 \\
\hline Belgium & 3.802 & 3.331 & 1 & 9.411 & 3.407 & 1 \\
\hline Denmark & 4.235 & 4.308 & 0 & 4.639 & 8.059 & 0 \\
\hline France & 1.934 & 2.021 & 0 & 2.435 & 2.180 & 1 \\
\hline Germany & 3.000 & 3.171 & 0 & 3.244 & 3.052 & 1 \\
\hline Italy & 3.247 & 2.349 & 1 & 3.902 & 2.657 & 1 \\
\hline Netherlands & 3.164 & 2.440 & 1 & 3.480 & 2.449 & 1 \\
\hline Norway & 10.317 & 9.990 & 1 & 9.194 & 9.817 & 0 \\
\hline Switzerland & 2.914 & 3.041 & 0 & 2.790 & 2.784 & 1 \\
\hline Canada & 3.243 & 3.661 & 0 & 6.057 & 4.711 & 1 \\
\hline Japan & 3.763 & 3.599 & 1 & 14.569 & 4.456 & 1 \\
\hline Finland & 4.790 & 4.985 & 0 & 7.052 & 5.019 & 1 \\
\hline Malta & 9.040 & 5.303 & 1 & 23.071 & 5.397 & 1 \\
\hline Portugal & 4.030 & 3.658 & 1 & 5.169 & 3.873 & 1 \\
\hline Spain & 3.003 & 3.491 & 0 & 4.075 & 3.562 & 1 \\
\hline New Zealand & 4.590 & 4.306 & 1 & 5.480 & 4.340 & 1 \\
\hline Cyprus & 6.093 & 6.088 & 1 & 5.964 & 6.706 & 0 \\
\hline Israel & 8.338 & 7.555 & 1 & 9.365 & 7.827 & 1 \\
\hline Korea & 8.746 & 6.601 & 1 & 10.559 & 6.335 & 1 \\
\hline Slovak Republic & 12.142 & 8.449 & 1 & 103.860 & 6.755 & 1 \\
\hline Latvia & 16.049 & 8.904 & 1 & 258.976 & 7.547 & 1 \\
\hline \multicolumn{3}{|c|}{ Panel model outperforms (\%) } & 65 & & & $83 * * *$ \\
\hline \multicolumn{7}{|c|}{$\begin{array}{l}\text { Notes: This table shows the out-of-sample forecasting errors (RMSE) of } 4 \text { quarters ahead GDP growth } \\
\text { from an individual country model and a panel model. Model } 1 \text { is an AR model with lags chosen by AIC } \\
\text { Model } 2 \text { adds credit growth and policy variables to the AR model. The bottom row is the percentage of } \\
\text { cases in which the panel model outperforms the individual country model. *, **, and *** indicate } \\
\text { statistical significance at the } 1 \text { percent, } 5 \text { percent, and } 10 \text { percent level, respectively. }\end{array}$} \\
\hline
\end{tabular}


Table 9. Comparing Panel and Individual Country Model Performance: Emerging Markets

Panel A: In sample

\begin{tabular}{|c|c|c|c|c|c|c|}
\hline \multirow[t]{2}{*}{ Country } & \multicolumn{3}{|c|}{ Model 1 (AR) } & \multicolumn{3}{|c|}{ Model 2 (AR and Credit) } \\
\hline & $\begin{array}{l}\text { Individual } \\
\text { RMSE }\end{array}$ & $\begin{array}{l}\text { Panel } \\
\text { RMSE }\end{array}$ & $\begin{array}{c}1 \text { if Panel } \\
\text { outperforms }\end{array}$ & $\begin{array}{l}\text { Individual } \\
\text { RMSE }\end{array}$ & $\begin{array}{l}\text { Panel } \\
\text { RMSE }\end{array}$ & $\begin{array}{c}1 \text { if Panel } \\
\text { outperforms }\end{array}$ \\
\hline Turkey & 10.761 & 11.976 & 0 & 8.821 & 10.784 & 0 \\
\hline Brazil & 5.441 & 6.652 & 0 & 4.533 & 6.092 & 0 \\
\hline Colombia & 7.315 & 8.277 & 0 & 5.531 & 7.309 & 0 \\
\hline Costa Rica & 4.923 & 6.184 & 0 & 4.191 & 6.049 & 0 \\
\hline Ecuador & 6.028 & 6.783 & 0 & 4.247 & 7.626 & 0 \\
\hline Guatemala & 5.453 & 5.762 & 0 & 1.671 & 6.773 & 0 \\
\hline Peru & 9.697 & 9.939 & 0 & 7.602 & 8.697 & 0 \\
\hline Egypt & 5.427 & 6.881 & 0 & 4.872 & 6.850 & 0 \\
\hline Indonesia & 6.352 & 6.657 & 0 & 4.729 & 5.979 & 0 \\
\hline Malaysia & 11.540 & 11.108 & 1 & 6.109 & 7.811 & 0 \\
\hline Philippines & 5.987 & 6.223 & 0 & 4.665 & 5.416 & 0 \\
\hline Thailand & 7.679 & 8.151 & 0 & 6.850 & 8.118 & 0 \\
\hline Armenia & 0.000 & 8.086 & 0 & 0.000 & 7.504 & 0 \\
\hline Bulgaria & 6.504 & 7.580 & 0 & 5.513 & 7.631 & 0 \\
\hline Hungary & 7.453 & 8.137 & 0 & 7.022 & 8.181 & 0 \\
\hline Croatia & 4.802 & 5.428 & 0 & 3.596 & 5.007 & 0 \\
\hline Romania & 6.755 & 7.889 & 0 & 6.095 & 7.734 & 0 \\
\hline \multicolumn{3}{|c|}{ Panel model outperforms (\%) } & 6 & & & 0 \\
\hline \multicolumn{7}{|c|}{$\begin{array}{l}\text { Notes: This table shows the in-sample forecasting errors (RMSE) of } 4 \text { quarters ahead GDP growth } \\
\text { from an individual country model and a panel model. Model } 1 \text { is an AR model with lags chosen by } \\
\text { AIC. Model } 2 \text { adds credit growth and policy variables to the AR model. The bottom row is the } \\
\text { percentage of cases in which the panel model outperforms the individual country model. *, **, and } \\
* * * \text { indicate statistical significance at the } 1 \text { percent, } 5 \text { percent, and } 10 \text { percent level, respectively. }\end{array}$} \\
\hline
\end{tabular}


Table 8. Comparing Panel and Individual Country Model Performance: Emerging Markets (cont')

Panel B: Out of sample

\begin{tabular}{|c|c|c|c|c|c|c|}
\hline \multirow[t]{2}{*}{ Country } & \multicolumn{3}{|c|}{ Model 1 (AR) } & \multicolumn{3}{|c|}{ Model 2 (AR and Credit) } \\
\hline & $\begin{array}{c}\text { Individual } \\
\text { RMSE }\end{array}$ & $\begin{array}{l}\text { Panel } \\
\text { RMSE }\end{array}$ & $\begin{array}{c}1 \text { if Panel } \\
\text { outperforms }\end{array}$ & $\begin{array}{l}\text { Individual } \\
\text { RMSE }\end{array}$ & $\begin{array}{l}\text { Panel } \\
\text { RMSE }\end{array}$ & $\begin{array}{c}1 \text { if Panel } \\
\text { outperforms }\end{array}$ \\
\hline Turkey & 14.752 & 10.411 & 1 & 22.197 & 9.432 & 1 \\
\hline Brazil & 8.879 & 5.863 & 1 & 8.879 & 5.099 & 1 \\
\hline Colombia & 16.349 & 6.715 & 1 & 19.428 & 5.636 & 1 \\
\hline Peru & 19.225 & 9.181 & 1 & 43.486 & 8.766 & 1 \\
\hline Indonesia & 13.260 & 6.984 & 1 & 14.539 & 6.318 & 1 \\
\hline Malaysia & 14.515 & 10.304 & 1 & 13.002 & 9.465 & 1 \\
\hline Philippines & 5.529 & 5.379 & 1 & 6.442 & 5.082 & 1 \\
\hline Thailand & 8.760 & 5.465 & 1 & 38.981 & 4.965 & 1 \\
\hline Hungary & 11.239 & 8.648 & 1 & 20.567 & 8.826 & 1 \\
\hline \multicolumn{3}{|c|}{ Panel model outperforms (\%) } & $100 * * *$ & & & $100 * * *$ \\
\hline \multicolumn{7}{|c|}{$\begin{array}{l}\text { Notes: This table shows the out-of-sample forecasting errors (RMSE) of } 4 \text { quarters ahead GDP growth } \\
\text { from an individual country model and a panel model. Model } 1 \text { is an AR model with lags chosen by AIC } \\
\text { Model } 2 \text { adds credit growth and policy variables to the AR model. The bottom row is the percentage of } \\
\text { cases in which the panel model outperforms the individual country model. *, } * * \text {, and } * * * \text { indicate } \\
\text { statistical significance at the } 1 \text { percent, } 5 \text { percent, and } 10 \text { percent level, respectively. }\end{array}$} \\
\hline
\end{tabular}


Table 10. Comparing WEO Forecasts with Simple Financial Model

\begin{tabular}{|c|c|c|c|c|c|}
\hline \multirow[t]{2}{*}{ Country } & \multicolumn{2}{|c|}{ WEO forecasts } & \multicolumn{2}{|c|}{ Model 2 (AR+Credit) } & \multirow[t]{2}{*}{$\begin{array}{c}1 \text { if Model } 2 \\
\text { outperforms WEO }\end{array}$} \\
\hline & RMSE & No. of obs & RMSE & No. of obs & \\
\hline United States & 3.127 & 12 & 2.321 & 19 & 1 \\
\hline United Kingdom & 4.076 & 18 & 3.269 & 19 & 1 \\
\hline Austria & 3.332 & 18 & 2.858 & 18 & 1 \\
\hline Belgium & 3.592 & 18 & 3.015 & 15 & 1 \\
\hline France & 2.544 & 18 & 2.312 & 19 & 1 \\
\hline Germany & 3.111 & 18 & 3.308 & 18 & 0 \\
\hline Italy & 3.985 & 18 & 3.743 & 18 & 1 \\
\hline Sweden & 4.020 & 12 & 3.294 & 11 & 1 \\
\hline Switzerland & 2.412 & 14 & 2.147 & 19 & 1 \\
\hline Canada & 2.856 & 16 & 3.765 & 10 & 0 \\
\hline Japan & 3.511 & 16 & 3.651 & 19 & 0 \\
\hline Finland & 4.128 & 18 & 4.392 & 18 & 0 \\
\hline Greece & 6.180 & 18 & 5.353 & 18 & 1 \\
\hline Iceland & 1.954 & 1 & 6.519 & 13 & 0 \\
\hline Portugal & 3.234 & 17 & 3.247 & 18 & 0 \\
\hline Spain & 3.300 & 16 & 2.732 & 18 & 1 \\
\hline Turkey & 9.021 & 5 & 5.017 & 19 & 1 \\
\hline New Zealand & 4.846 & 5 & 3.065 & 15 & 1 \\
\hline Brazil & 4.973 & 2 & 3.631 & 19 & 1 \\
\hline Mexico & 1.576 & 3 & 5.454 & 11 & 0 \\
\hline Peru & 2.024 & 3 & 4.977 & 19 & 0 \\
\hline Cyprus & 3.218 & 5 & 2.839 & 8 & 1 \\
\hline Israel & 4.415 & 12 & 3.292 & 8 & 1 \\
\hline India & 12.193 & 4 & 4.135 & 13 & 1 \\
\hline Korea & 5.514 & 14 & 3.646 & 19 & 1 \\
\hline Malaysia & 4.161 & 2 & 6.982 & 18 & 0 \\
\hline Philippines & 6.095 & 5 & 2.711 & 19 & 1 \\
\hline Thailand & 7.678 & 5 & 3.716 & 16 & 1 \\
\hline Russia & 7.166 & 5 & 4.258 & 5 & 1 \\
\hline Croatia & 7.486 & 5 & 3.973 & 19 & 1 \\
\hline Slovenia & 7.675 & 12 & 4.078 & 18 & 1 \\
\hline Romania & 4.419 & 3 & 7.029 & 16 & 0 \\
\hline \multicolumn{5}{|c|}{ Model 2 outperforms WEO (\%) } & $69 * *$ \\
\hline \multicolumn{6}{|c|}{$\begin{array}{l}\text { Notes: This table shows out-of-sample forecasting errors (RMSE) of } 4 \text { quarters ahead GDP growth. } \\
\text { Model } 2 \text { adds credit growth and policy variables to an AR model with lags chosen by AIC. The bottom } \\
\text { row is the percentage of cases in which model } 2 \text { outperforms WEO forecasts. Statistical significance is } \\
\text { shown for a two-tailed binomial test. } *{ }^{* *} \text {, and } * * * \text { indicate statistical significance at the } 1 \text { percent, } 5 \\
\text { percent, and } 10 \text { percent level, respectively. }\end{array}$} \\
\hline
\end{tabular}


Table 11. Comparing WEO Forecasts with Expanded Financial Model

\begin{tabular}{|c|c|c|c|c|c|}
\hline \multirow{2}{*}{ Country } & \multicolumn{2}{|c|}{ WEO forecasts } & \multicolumn{2}{|c|}{$\begin{array}{c}\text { Model } 3 \\
(\mathrm{AR}+\text { Credit+Equity }+ \text { Housing })\end{array}$} & \multirow{2}{*}{$\begin{array}{c}\text { Model } 3 \\
\text { outperforms } \\
\text { WEO }\end{array}$} \\
\hline & RMSE & No. of obs & RMSE & No. of obs & \\
\hline United States & 3.127 & 12 & 1.774 & 9 & 1 \\
\hline United Kingdom & 4.076 & 18 & 2.882 & 9 & 1 \\
\hline Austria & 3.332 & 18 & 2.341 & 9 & 1 \\
\hline Belgium & 3.592 & 18 & 2.521 & 4 & 1 \\
\hline France & 2.544 & 18 & 1.918 & 9 & 1 \\
\hline France & 2.544 & 18 & 1.918 & 9 & 1 \\
\hline Germany & 3.111 & 18 & 2.702 & 9 & 1 \\
\hline Italy & 3.985 & 18 & 3.285 & 9 & 1 \\
\hline Sweden & 4.020 & 12 & 2.620 & 7 & 1 \\
\hline Canada & 2.856 & 16 & 3.262 & 7 & 0 \\
\hline Japan & 3.511 & 16 & 3.384 & 9 & 1 \\
\hline Finland & 4.128 & 18 & 3.488 & 9 & 1 \\
\hline Finland & 4.128 & 18 & 3.488 & 9 & 1 \\
\hline Greece & 6.180 & 18 & 5.072 & 7 & 1 \\
\hline Iceland & 1.954 & 1 & 5.170 & 9 & 0 \\
\hline Portugal & 3.234 & 17 & 3.027 & 9 & 1 \\
\hline Spain & 3.300 & 16 & 2.143 & 9 & 1 \\
\hline New Zealand & 4.846 & 5 & 2.490 & 8 & 1 \\
\hline Brazil & 4.973 & 2 & 3.432 & 7 & 1 \\
\hline Peru & 2.024 & 3 & 5.070 & 9 & 0 \\
\hline Israel & 4.415 & 12 & 3.559 & 8 & 1 \\
\hline Malaysia & 4.161 & 2 & 6.812 & 7 & 0 \\
\hline Philippines & 6.095 & 5 & 2.870 & 5 & 1 \\
\hline Thailand & 7.678 & 5 & 3.329 & 3 & 1 \\
\hline Russia & 7.166 & 5 & 6.111 & 9 & 1 \\
\hline Romania & 4.419 & 3 & 2.320 & 5 & 1 \\
\hline \multicolumn{5}{|c|}{ Model 3 outperforms WEO (\%) } & $85 * *$ \\
\hline \multicolumn{6}{|c|}{$\begin{array}{l}\text { Notes: This table shows out-of-sample forecasting errors (RMSE) of 4-quarter ahead GDP growth. } \\
\text { Model } 3 \text { adds credit, stock price, and house price growth and policy variables to an AR model with lags } \\
\text { chosen by AIC. The bottom row is the percentage of cases in which model } 3 \text { outperforms WEO forecasts. } \\
\text { Statistical significance is shown for a two-tailed binomial test. *, } * * \text {, and } * * * \text { indicate statistical } \\
\text { significance at the } 1 \text { percent, } 5 \text { percent, and } 10 \text { percent level, respectively. }\end{array}$} \\
\hline
\end{tabular}




\section{REFERENCES}

Bernanke, Ben, Mark Gertler, and Simon Gilchrist, 1996, "The Financial Accelerator and the Flight to Quality," Review of Economics and Statistics, Vol. 78(1): 1-15.

Claessens, Stijn, Ayhan, Kose, and Marco Terrones, 2008, "What Happens During Recessions, Crunches and Busts?", IMF WP/08/274

ECB, 2004, European Central Bank Monthly Bulletin, December 2004, European Central Bank.

Arturo Estrella and Frederic S. Mishkin, 1998, "Predicting U.S. Recessions: Financial Variables as Leading Indicators," Review of Economics and Statistics, Vol 80(1): 45-61.

Garcia-Ferrer, A., R. A. Highfield, F. Palm and A. Zellner, 1987, "Macroeconomic Forecasting Using Pooled International Data," Journal of Business \& Economic Statistics Vol. 5(1): 53-67

Gilchrist, Simon and Egon Zakrajšek, 2012, "Credit Spreads and Business Cycle Fluctuations," American Economic Review, 102(4): 1692-1720.

Hoogstrate AJ, FC Palm, GA Pfann2000, "Pooling in dynamic panel-data models: An application to forecasting GDP growth rates," Journal of Business \& Economic Statistics Vol. 5(1): 53-67

Iacoviello, Matteo, 2012, "Housing Wealth and Consumption," International Encyclopedia of Housing and Home, pp. 673-678, Elsevier.

IMF, 2016, "2016 Handbook of IMF Facilities for Low-Income-Countries," International Monetary Fund.

Leamer, Edward, 2007. "Housing is the business cycle," Proceedings - Economic Policy Symposium - Jackson Hole, Federal Reserve Bank of Kansas City, pages 149-233

Philippon Thomas, 2009. "The Bond Market's q," The Quarterly Journal of Economics, Vol. 124(3): 1011-1056.

Stock, James H. and Mark W. Watson, 2003, "Forecasting Output and Inflation: The Role of Asset Prices," Journal of Economic Literature, Vol.(XLI): 788-829. 


\section{APPENDiX}

Table A1. Data Source

\begin{tabular}{lll}
\hline \hline Variable & Definition & Source \\
\hline GDP & Gross domestic product, volume & IFS \\
Private consumption & Household consumption expenditure & IFS \\
Private investment & Gross fixed capital formation & IFS \\
CPI & Consumer price index & IFS \\
Credit & Claims on private sector & IFS \\
Stock price & Share price index & Bloomberg \\
House price & House price & OECD and BIS \\
Deposit rate & Deposit rate & IFS \\
Lending rate & Lending rate & IFS \\
Sovereign bond yield & Sovereign credit default swap, 10 year maturity & Bloomberg \\
Corporate bond yield & Barclay global aggregate corporate bond index & Bloomberg \\
Government consumption & Government final consumption expenditure & IFS \\
Short term interest rate & Central bank policy rate or discount rate & IFS \\
GDP deflator & Gross domestic product deflator index & IFS \\
& Real GDP growth computed from gross domestic product & \\
WEO forecasts & (current prices) & WEO \\
\hline
\end{tabular}

Table A2. Country List

Group 1 (Advanced Economies) $\quad$ Full sample

Australia, Austria, Belgium, Canada, Cyprus, Denmark, Finland, France, Germany, Greece, Iceland, Ireland, Israel, Italy, Japan, Korea, Latvia, Malta, Netherlands, New

Zealand, Norway, Portugal, Slovak Republic, Slovenia, Spain, Sweden, Switzerland, United Kingdom, United States

Subsample with bond yields

Australia, Canada, France, Germany, Italy, Japan, Netherlands, Spain, Sweden, Switzerland, United Kingdom, United States

Group 2 (Emerging markets)

Albania, Armenia, Botswana, Brazil, Bulgaria, Chile, Colombia, Costa Rica, Croatia, Ecuador, Egypt, Georgia, Guatemala, Hungary, India, Indonesia, Iran, Kazakhstan, Macedonia, Malaysia, Mauritius, Mexico, Paraguay, Peru, Philippines, Romania, Russia, South Africa, Thailand, Turkey

Group 3 (Low-income countries) 1/ Bolivia, Kyrgyz Republic, Moldova Source: IMF WEO, IMF (2016)

Notes: Bolivia graduated from PRGT-eligibility on October 16, 2015 but is included in our low-income countries regression. 